\title{
Kernos
}

Revue internationale et pluridisciplinaire de religion grecque antique

$28 \mid 2015$

Varia

\section{The Documents in Sokolowski's Lois sacrées des cités grecques. Supplément (LSS)}

\section{Edward Harris and Jan-Mathieu Carbon}

\section{(2) OpenEdition \\ Journals}

Electronic version

URL: http://journals.openedition.org/kernos/2561

DOI: 10.4000/kernos.2561

ISSN: 2034-7871

\section{Publisher}

Centre international d'étude de la religion grecque antique

Printed version

Date of publication: 1 October 2015

ISBN: 978-2-87562-055-2

ISSN: 0776-3824

Electronic reference

Edward Harris and Jan-Mathieu Carbon, «The Documents in Sokolowski's Lois sacrées des cités grecques. Supplément (LSS) », Kernos [Online], 28 | 2015, Online since 01 April 2018, connection on 14 November 2019. URL : http://journals.openedition.org/kernos/2561 


\section{The Documents in Sokolowski's Lois sacrées des cités grecques. Supplément (LSS)}

This list of the documents found in Lois sacrées des cités grecques. Supplément attempts to classify them in terms of the categories formulated in Harris, “Towards a Typology" (2015).

\section{Athens (Agora). Law/decree of the polis (?) - between 510 and 480 BCE $\left(I G \mathrm{I}^{3} 231 ; I E 7\right)$}

This fragmentary inscription is written in boustrophedon, which dates the text to the late sixth or the early fifth century BCE; Clinton dates the inscription more precisely to 510-500 BCE. Perquisites for officials at the Greater (lines A3-5) and Lesser Mysteries appear to be listed (line A6-7, 11-12). A priestess appears to be mentioned in line 13. At lines A14 and B3, the mention of the phaidyntes, an ancient cult official at Eleusis, is relatively clear; see Clinton and no. 3 below. Sokolowski restored the names of the priestly gene of the Kerykes and Eumolpidai (lines A1-2, C3), but Lewis in $I G \mathrm{I}^{3}$ reports these only in the apparatus criticus, and Clinton calls these and other restorations "speculative". For discussion see Clinton (1974), 10, 95.

\section{Athens. Expenses for a cult (genos?) - between 510 and 480 $\operatorname{BCE}\left(I G \mathrm{I}^{3} 232 ; C G R N 7\right)$}

There are several fragments, which are not well preserved but contain a list of various types of liquid (e.g. wine) and solid (e.g. barley) offerings. Sokolowski gives only fragments $\mathrm{Aa}$ and Ac. He restores the epithet Kourotrophos in line Aa5; Zeus Polieus appears to be mentioned at Ac12-13 (cf. also Aa15). Each god is prefaced by punctuation which demarcates a new entry in the list. Lewis in $I G$ $I^{3} 232$ prints more fragments and calls the document a lex sacra. It is not clear to which type of document this belongs; according to Jeffery, it may have be an account of offerings belonging to the genos of the Kerykes and set up at the City Eleusinion (for which see no. 3 below). It appears to have been organised according to the specific deity concerned by the rituals. See CGRN for further commentary. 


\section{Athens (Agora). Law/decree of the polis - middle of the fifth century (IG $\mathrm{I}^{3} 6 ; I E$ 19)}

The text is inscribed on three sides of a marble stele and contains rules about the Greater and Lesser Mysteries at Eleusis. It has been identified with the law mentioned at Andocides 1.116. In what follows we use the line numbers found in IE 19. The text on Side A is not well preserved, but appears to contain rules about the use of the sanctuary of Demeter at Eleusis and to contain several clauses in the casuistic form (lines A7-8, 11-12, 17-18, 26-27, 27-28, 28-30, 31$32,32-34,38-40)$. Line A2 may contain a penalty in drachmas (Sokolowski), and lines A35-36 appear to grant powers to the Council. Lines A25-26 appear to deny access to the shrine for those cities that do not turn over a debtor who owes money to the sanctuary. For denying a city access to an international sanctuary compare Thuc. 5.49-50 and LSCG 78 (CID IV, 1 / IG II 1126 / Syll. ${ }^{3}$ 145), lines 39-40, 47-48 with Harris (2015), 62. Clinton proposes the following translation for lines A36-40: "Of Athenians (none) is to be expelled from these cities nor anywhere to be disturbed except for those convicted in a local court or discovered among the enemy". The final clause (lines A40-43) refers to what will happen to cities that choose to opt out of this arrangement: recourse is given to arbitration with the Athenians conducted according to symbola, for which see Gauthier (1972), 157-205 (158 on this passage). The text on Side B is better preserved. Lines B4-8 appear to contain a clause about penalties for offenses committed unwillingly (penalty $=$ simple restitution) and those committed willingly (double restitution). Compare Dem. 21.43 for the rule. The next section concerns the sacred truce for initiates (mystai) and visitors (epoptai) (lines B8-17), which lasts from the middle of Metageitnion through Boedromion until 10 Pyanopsion (lines B17-27 with Mikalson [1975], 54-62). The truce is valid for Athenians and for the cities that use the shrine (lines B2736). For the Lesser Mysteries, the truce lasts from the middle of Gamelion through Anthesterion until 10 Elaphebolion (lines A36-47; the last day coincides-but perhaps did not overlap_-with the first day of the City Dionysia, see Mikalson [1975], 126-127). The text on Side C is less well preserved. For detailed discussion see Clinton (1974), 10-15. The first clause gives the bierokeryx the right to collect half an obol from each initiate (lines C69). The priestess of Demeter has the right to collect one obol from each initiate at the Lesser Mysteries and one obol at the Greater Mysteries (lines C9-14). All the money is to belong to the two goddesses except for 1,600 drachmas; the priestess is to use the latter amount to pay for specific expenses (lines C13-16). The Eumolpidai and the Kerykes are to receive perquisites from the animals 
sacrificed (lines C20-24). Each male initiate is to give five obols, each female initiate three obols (lines C20-23). The Kerykes and the Eumolpidai are to perform the initation for each initiate separately; if they initiate several at a time, they are to be fined 1,000 drachmas (lines C26-31). The Athenians are permitted to "use" (borrow) the money from the aparche just as they use Athena's funds (C32-36). The hieropoioi are to serve as treasurers for the money of the goddesses on the Acropolis (lines C36-38). There appears to be a provision about the initiation of orphans (lines C39-42). The initiates at Eleusis are to be initiated in the courtyard, and the initiates in the city, in the City Eleusinion (lines C43-46). For the City Eleusinion, see Miles (1998). Sokolowski believed that this clause pertained to sacrifices, but see Clinton (1974), 12. The priest at the altar, the phaidyntes for the two goddesses, and the priest are each to receive half an obol sacred to the goddesses from each initiate (lines C47-50). There are traces of letters on the remaining side of the stele, but not enough remains to permit the secure restoration of any words.

There is no enactment formula preserved, but the rules are clearly part of a law/decree of the polis and mention several public officials as well as the Council. What is interesting to observe is what the rules contain and what they do not contain. The rules primarily concern financial matters, especially the fees to be paid by initiates, the dates of the sacred truces, and penalties for communities that do not observe the truce. On the other hand, the rules do not indicate how the priests are to conduct the initiations, which no doubt followed the ancestral traditions of the Kerykes and Eumolpidai. Yet the polis regulates the way in which the initiations are conducted by forbidding initiations en masse or in any sort of group, and it has the power to use the money from the aparche collected for the sanctuary. See also no. 12 below.

\section{Athens. Law/decree of the polis - late fifth century BCE $\left(I G \mathrm{I}^{3}\right.$ 257)}

Even though the prescript with an enactment formula is not preserved, the rule must be a law/decree of the polis because it assigns enforcement to the basileus (lines 1-2). Two stelai were to be set up with the law, "one on each side" (of the sanctuary or the river, lines 2-4). The rule forbids anyone to tan hides or to dip them in the river Ilissos above the sanctuary of Heracles (lines 4-8) or to throw rubbish into the river (lines 8-10). Sokolowski compares this regulation with several similar regulations about keeping sanctuaries clean: [Arist.] Ath. Pol. 50.2; and LSS 24, 50, and 53. On rules for fountains, see also Kah (2012). 


\section{Athens (Acropolis). Sign (polis or private association?) - middle of the fifth century BCE (IG $\left.\mathrm{I}^{3} 1382\right)$}

Because of its brevity and placement, this should be classified as a sign. The text is inscribed into the face of a rock on the north slope of the Acropolis. For a photograph of the location, see Broneer (1932), 42. It mentions a festival for Eros on the fourth of Mounichion; see Mikalson (1975), 18 and 138-139, who thinks that the ritual should be that of a private association. On balance, however, the reference seems to be to a public occasion. The designation of the periodic ritual in question as he heorte - a term exceptionally rarely employed by individuals or private associations-points to a public festival (of Eros and probably Aphrodite, who was usually honoured on the 4th day of the month), celebrated either by the polis or by one of its subgroups. For other probably public signs of this sort, see e.g. nos. 73 and 74 below.

\section{Athens. Law/decree of the polis - late fifth century BCE (IG $\mathrm{I}^{3}$ 136; CGRN44)}

This is a decree of the Assembly and begins with the name of the secretary and an enactment formula (lines 1-3). The decree has been reconstructed from fragments; Lewis arranges the fragments in a different way from Sokolowski, who followed Roussel and Bingen; for that arrangement of the text, see also CGRN.

If the restoration in line 3 is correct, the decree can be dated to $413 / 2$ BCE. The decree concerns the cult of Bendis, which was introduced to Athens in the second half of the fifth century BCE. The decree is very fragmentary but clearly enacts rules about the cult of Bendis. Sokolowski thought that the decree established the cult. Lines 3-4 may refer to a procession from the city. Lines 4-5 appear to order prayers and sacrifices by each tribe. Line 10 may mention paredroi. Line 11 pertains to another sacrifice, and line 13 to a pannychis. Lines 15-19 appear to order men to consult the god at the oracle about who

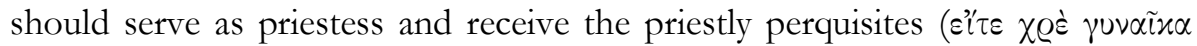

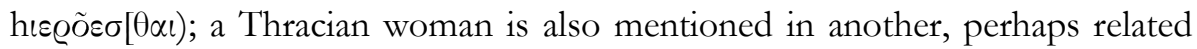
fragment (line 15). Line 19-20 appear to order the bieropoioi to cast lots about the priesthood in the future. Line 22 orders a payment by the kolakretai, an office that appears to have been abolished around $411 \mathrm{BCE}$ (see [Arist.] Ath. Pol. 30.2 with Harris [1990], 257). Line 23 appears to delegate powers to the Council to implement the terms of the decree. For similar clauses see Harris (2016), 79 with n. 29. Lines 23-25 contain a clause about publication. On these 
clauses about where decrees are to be posted, see Liddel (2003). Lewis restores the beginning of a rider to the decree in the next lines.

\section{Athens. Law/decree (polis) - around $435 \mathrm{BCE}\left(I G \mathrm{I}^{3} 129\right)$}

Only a few letters of the first line remain, but they appear to contain an enactment formula. The second line mentions the poletai. There appear to be rules concerning supplies for purifications, such as wood (line 5) and piglets (line 7), which was followed by an order for disposing of the katharmata, the remnants of the cleansing purification (lines 8-10). At the conclusion of the fragment, there is a clause in the casuistic form imposing a penalty on those who do not obey the rule (lines 10-12).

\section{Athens. Law/decree (polis) - around $430 \mathrm{BCE}\left(I G \mathrm{I}^{3} 137\right)$}

This is a law/decree of the Assembly starting with an enactment formula (lines 1-3). The rules concern a cult of Apollo, and there appears to be a reference to an oracle (line 4: $\dot{\alpha} \nu \varepsilon \bar{\imath} \lambda \varepsilon$ ). A throne is ordered to be taken out of the sanctuary, perhaps during a certain ceremony (line 5). There appears to be an order to the epistatai to distribute meat to citizens, as well as perhaps financial considerations relating to perquisites (lines $7-10$ ). In $I G \mathrm{I}^{3} 137$, Lewis is sceptical about Sokolowski's restorations; Rosivach (1994), 154, views this as a one-off order rather than a law/decree, but no certainty is possible.

\section{Athens. Agora. Calendar (polis) - 410-404 BCE (IG $\mathrm{I}^{3} 240$; Lambert 2002; CGRN 45)}

Sokolowski printed the two fragments from a calendar and, following Dow, associated them with the revision of the laws. Lewis put these two fragments together with two more fragments (IG I3 240). See Lambert (2002) for a republication of all the fragments attributed to this revision (here from the earlier Face B [Ionic script], fr. 10 and 11). On the revision of the laws see now Canevaro and Harris (2012), and Canevaro and Harris (2016), 33-47, esp. 42-45. See no. 10 below. 


\section{Athens. Calendar (polis) - 403-399 BCE (?) (Lambert 2002; CGRN45)}

Following Dow, Sokolowski associated these two fragments of a calendar with the revision of the laws in the period 403-399 BCE. There are names of several months_Skirophorion (line A19), Hekatombaion (line 29). Civic subgroups (tribes, etc) and personnel (phylobasileis) are mentioned throughout.

On the fragments see Lambert (2002), for a new edition (Sokolowski's A and $\mathrm{B}$ is included as Face A, later face, Attic script, fr. 3 and fr. 8 respectively). Sokolowski believes that these fragments come from a wall of the Stoa Basileios on the basis of the document found at Andoc. 1.81, but see no. 9 above with Canevaro and Harris (2016) 42-45.

\section{Athens. Piraeus. Decree (polis) - early fourth century BCE (IG II $^{2}$ 47; CGRN 46)}

This inscription contains an inventory of items (IG II ${ }^{2} 47$, lines 1-22) and a decree of the Assembly (IG II ${ }^{2} 47$, lines 23-39). Sokolowski prints only the decree of the Assembly. This has an abbreviated enactment formula (lines 1-3). Euthydemus, the priest of Asclepius (cf. $I G \mathrm{II}^{2}$ 4962), has given expert advice (exegesis) about the prothymata (preliminary offerings) for Asclepius, and the Assembly orders that these offerings and the rest of the sacrifice be carried out for the benefit of the people (lines 3-6). The epistatai of Asclepius are to offer the prothymata from the money collected from quarrying (according to Papazarkadas [2011], 42 n. 109, with a new reading of lines 8-9, a quarry whose property and proceeds were reserved for the god), and the rest is to be spent on the building of a shrine (lines 6-10). The hieropoioi are ordered to supervise the distribution of meat for the people during the public festival (lines 11-13). Portions of the hegemon boos (ox leading the procession) are to be given to the prytaneis, the nine archons, the bieropoioi and the leaders of the procession with the rest distributed to the Athenians (lines 13-17). One should note that it is the priest who determines the way in which the ritual is to be performed. The Assembly ratifies his expert advice and rules about financial matters and perquisites.

\section{Athens. Law/decree (polis) - fourth century CE (IE 138)}

When Sokolowski included his text of this law/decree in LSS, only one fragment of the law/decree had been published. After the publication of LSS, 
Clinton (1980) published several more fragments, which have now been included in his collection of inscriptions from Eleusis (IE 138), whose line numbers we use in what follows. Clinton gives a good summary of the contents: "the announcement of the Mysteries and the selection and sending of the spondophoroi to the other Greek cities (A.1-13), the limits and nature of the Sacred Truce surrounding the festival (lines 14-17), the behavior of the cities toward the spondophoroi and the report of the latter on their mission (lines 2026), regulations concerning myesis (lines 27-29), the appointment of the epimeletai, their duties and those of the basileus in managing the festival (lines 2938), the duties of the exegetes before the festival (lines 38-40), an unclear selection by lot (lines 41-42), and (after a long lacuna) regulations pertaining to the initiates (B.D, $f$ ) and procession (B.g), legal procedures and penalties for various infractions $(\mathrm{B}, h, a)$, and the general responsibilties of the epistatai (B.a.23-24)." There are several public officials mentioned: hierophants (lines A7), thesmothetai (lines A, 14, A 46), spondophoroi (line A20), archon (line A 21), basileus (lines A24, A 28, A 35,A 36-37, A 41-42, A 50), epimeletai (lines A29-33), praktores (lines A34), exegetai (line A 38), secretary (A34).

As in a previously discussed text (no. 3 above), the Assembly is concerned primarily with the Sacred Truce, which pertains to Athenian relations with other Greek communities, with the duties of officials and their powers to levy fines on those who disrupt the festival, and with legal procedures. The actual rituals involving initiation are left in the hands of the gene of the Eumolpidai and Kerykes, who are still subject to control by the state, especially in financial matters.

\section{Athens. Law (nomos) (polis) - 353/2 BCE (IG II $\left.{ }^{2} 140 ; I E 142\right)$}

This is a law (nomos-Clinton mistakenly calls it a "decree of the nomothetai") and enacted by the nomothetai (lines 1-8). For the procedure of legislation in the fourth century BCE see now Canevaro (2013b). The law is an addition to a law of Chaeremonides about the first-fruits (lines 8-10), but the Assembly is to decide about the manner in which the first-fruits are to be collected (lines 1013). The Council in the following year is to make sure that the first-fruits are given for Demeter and Persephone and the traditional rites (ta nomizomena) performed (lines 13-18). A pelanos (offering of a cake with grains taken from the aparche) is to be made according to the exegesis of the Eumolpidai (see also Clinton, IE 28a, lines 36-40), the rest of the Eleusinian offerings according to the decree (lines 19-25). After the first-fruits are collected, the Council is to make all the sacrifices according to the law (line 25-31). Sokolowski restores a 
reference to an oracle ( $\mu \alpha \nu \tau] \varepsilon i \alpha \nu)$ in lines $28-29$, but Clinton questions this and proposes another restoration (ė $\pi \mu \varepsilon \dot{\varepsilon} \lambda] \varepsilon\llcorner\alpha \nu$ ). The law orders the secretary of the Council to inscribe the decree on a stele in front of the Metroon next to the law of Chaeremonides (lines 31-35) and the treasurer of the people to give twenty drachmas from the funds for inscribing decrees (lines 35-38).

Clinton discusses the possible restorations of the number of the prytany and questions the proposal of Alessandrì (1980) to restore $\delta \varepsilon x \alpha$ in noted that the aparchai were collected in the ninth and tenth prytanies and that the law calls for the Council in the following year to supervise the collection of the aparchai. If the law were enacted before the ninth prytany, it would have ordered the Council in office at the time to supervise the collection. Clinton draws attention to the documents at Dem. 24.27, 39, 71 and appears to assume that the approval of laws took place only in Hekatombaion on the basis of the document at Dem. 24.20-23, but Canevaro (2013a) has shown that these documents are forgeries or do not contain reliable evidence. Canevaro has also shown that the approval of laws could take place at any time during the year. Alessandri's restoration is therefore the only one possible.

\section{Athens. Law/decree (polis) - 129/8 BCE (SEG 21, 469)}

There is a brief enactment formula followed by a long clause giving the reasons behind the decree, about the traditional piety of the Athenian people (lines 217). There follows a motivation clause about the Council and Assembly increasing the number of sacrifices and offerings so that they receive gratitude from the gods (line 17-20). The substance of the document is a regulation for renewal of the cult of Apollo Pythios. At lines 20-23, the proedroi are to make a proposal; the boule's resolution is to be submitted to the demos for approval. Lines 23ff. specify that sacrifices are to take place according to ancestral oracles; participation in the festival during the Thargelia en kepois is to involve the archon basileus, the archon, the strategoi. Several fragmentary lines follow, but mention is made (lines 33-37) of a procession accompanied by prayers during the Thargelia involving the priest of Apollo Pythios, the exegetai, the other civic priests, the nine archons, the hierophant, the daidouchos and "those that accompany him", the agonothetai of the games taking place in front of the Pythion, the choregoi of the year, the bieropoioi, and others now missing. The expression kata tapatria is mentioned in line 47. The kosmetes is mentioned in lines 48-49. Lines 49-63 deal with an apparent innovation, a sacrifice to Apollo Alexikakos; for a comprehensive discussion of the innovative character of this regulation, presenting itself as an ancestral norm, see Stavrianopoulou (2011), 
92-103. The location of the Pythion remains much debated; see Matthaiou (2011), 259-271.

\section{Athens. Law/decree (polis) - first or second century CE (IE 250)}

Sokolowski prints only lines 16-43 from the text of Oliver; Clinton prints a complete text with slightly different numeration and does not accept all of Oliver's and Sokolowski's restorations. Even though the first lines of the inscription are very fragmentary, this is clearly a law/decree of the Assembly because it concerns the public festival of the Eleusinian Mysteries and mentions several public officials. Clinton restores the phrase kata ta patria twice (lines 1415 in his text). The law/decree orders the mystagogoi to accompany the procession (lines 23-26). The mystagogoi and the epimeletai are to keep order and have the power to impose fines (lines 27-29). Anyone who wishes can bring a charge before the basileus or the epimeletai, and the case is to be tried in court (lines 29-32). The epimeletai are to bring these cases to court right after the procession (lines 32-35). The mystagogoi are to lead the procession as the epimeletai and the basileus order (lines 35-36). There appear to be rules about the route of the procession (lines 37-40). If a mystagogos does not follow the prescribed route, he is subject to the prescribed penalties (lines 40-42). The final lines appear to describe the reception of Iacchos (lines 42-43).

\section{Athens. Sign (private cult or private association) - first of second century CE (IG II $\left.{ }^{2} 4997 ; S E G 21,815\right)$}

The text is inscribed on a marble offering table and mentions an oracle of Hygieia and Asclepius (line 1). Line 2 mentions a "Celestial Serpent" which is possibly a guardian of the statues of the shrine. The rule prescribed by the oracle, perhaps resulting from a vision of the healing gods, consists in wineless sacrifices on the fifth and tenth of the month, "around midday" or "around the middle" (of some place-the table itself?-or group). For similar regular sacrifices in private cults and groups, compare e.g. the Dekatistai who regularly worshipped Isis and Sarapis. As expected (cp. e.g. $L S A M 72$ ), there is no sanction enforcing the oracle, and the text seems to conclude with a general injunction: "to the good (gods?) send a good (mixture?)" (we might also think to restore a blessing instead). 


\section{Attica. Phaleron. Sign on a private dedication - around 400 $\mathrm{BCE}\left(I G \mathrm{I}^{3} 987[\mathrm{~A}]+I G \mathrm{II}^{2} 4547[\mathrm{~B}]\right)$}

The texts are inscribed on a base supporting a relief (A) and on an altar (B). Text A reports that Xenokrateia set up a sanctuary of the river god Kephisos and dedicated it also to other gods sharing his altar as a gift "for teaching". Lines 6-7 contain a small rule that anyone who wishes may sacrifice "for fulfilled blessings". Text B contains the names of these deities which were associated and worshipped at the site (Hestia, Kephisos, Pythian Apollo, Leto, Artemis Lochias, Elethuia, Acheloos, Kallirhoe, the Nymphs (for discussion of their epithet see Sokolowski), and to Rhapso. The last goddess is otherwise unknown. See also Purvis (2003), 15-32 for further discussion.

\section{Attica. Paiania. Law/decree (deme) - fifth century BCE (IG $\mathrm{I}^{3}$ 250; CGRN25)}

This is a regulation of the deme concerning sacrificial provisions and other supplies for its cults of Demeter and related goddesses (Daira is invoked in line B16; the privileges of the priestess of Hekate are discussed in lines A33ff.). It might be thought that the regulation has a calendrical arrangement, but actually a few of the lists of provisions for festivals seem to be essentially repeated (for instance, the Antheia in lines A23ff. and B29ff.); the document rather appears to be a dossier collecting various requirements for certain festivals in the form of lists of supplies and expenses, including priestly prerogatives (apometra are often mentioned as items in the lists, cf. lines A6, A32, B23-24, B30-32), as well as including a variety of other rules. There are several victims to be sacrificed "at the Eleusinion" (lines A9, A30, B15-16, B26), i.e. the one in the city (on which, see above no. 3), others to be offered "here" (teide, cf. lines A7, B15 and 24), i.e. the sanctuary of Demeter in the deme, where the stele must have been displayed. There is a clause giving the bieropoioi the right to carry rhabdoi to discipline those who do not behave (lines B9-11). For a similar measure, see the law from Andania LSCG 65, lines 41-45. There is also a clause requiring a quorum of one hundred to be present for any changes to be voted to the law (lines B11-14). 


\section{Athens (Agora). Mediation between Two Private Groups and Decree (genos) - 363/2 BCE (R\&O 37; Lambert 1997; CGRN 84)}

This inscription records the terms of a mediation between the Salaminioi from Sounion and the Salaminioi from the Seven Tribes. For a revised text see Lambert (1997). After the date, the heading gives the names of the five arbitrators and states that the two groups have agreed to the following conditions (lines 2-8). The priesthoods of Athena Skiras, Heracles at Porthmos, Eurysakes, Aglauros and Pandrosos, and Kourotrophos are to be held in common (lines 8-16). The land at the sanctuary of Herakles at Porthmos, and the saltpan and agora at Koile are to be held in common (lines 16-19). All sacrificial animals provided by the city and by other officials are to be sacrificed in common with half for each party (lines 19-27). Sacrificial animals purchased from income from rents are sacrificed in traditional way. There is a list of perquisites to be given to priests and priestesses (lines 27-47). Each body of the Salaminioi will appoint an archon in turn to join with the priestess and herald to appoint oschophoroi and deipnophoroi in the ancestral way and write them up on a stele in the shrine of Athena Skiras (lines 47-52). The same man will be the priest for Eurysakes and for the hero of the saltpan (lines 52-54). Each group is to contribute equally for repairs to shrines (lines 54-56). In the archonship of Charicleides the Salaminioi of the Seven Tribes provided the archon (lines 5657). All written records are to be kept in common (lines 57-58). The lessee will work the land until the lease expires and give half of the rent to each group (lines 58-61). Each group takes turns in offering the preliminary sacrifice for the contest and take half the meat and the skins (lines 61-63). The priesthood of the herald is to belong to Thrasycles in the traditional manner (lines 63-65). Each side gives the other a full release from all claims, public and private (lines 65-67).

After the terms agreed by the mediation and a small gap, there follows a list of men from each group who swore the oaths to the agreement. The final part of the inscription contains a decree of the genos. This is a motion of Archeneos about sacrifices and a list of sacrifices and prices to be paid arranged by month (lines 80-95) — essentially a small sacrificial calendar of the genos. The inscription ends with an entrenchment clause, which provides for an action by the entire genos or a private action by anyone who wishes (lines 95-97). This shows that the genos relies on the courts of Athens to enforce this settlement. 


\section{Athens (Agora). By-laws (private association) - third century BCE (SEG 21, 530; CGRN102)}

This stele contains three decrees of the association, the first about loans (principal and interest) with instructions about publishing the names of borrowers and the amounts owed, as well as about republishing the ancestral decrees of the group (lines 2-11); these include the second decree cited directly below, about the sacrifices to be performed by the hestiator and portions of meat to be distributed (lines 12-23); another, now fragmentary decree appears to have followed in lines 24-25 and beyond. In the first decree, there is a rule about accounting for the expenditure of the stele (lines 9-11); in the second decree, a rule about not spending more than the income (line 17). There are two preserved enactment formulas (lines 2 and 12; a third is restored in line 24). The name of an official who will publish the names (lines 9-10: mnemon) and an official (line 12: hestiator) designated to carry out the sacrifice are mentioned, but penalties for the failure to perform duties are not.

\section{Attica. Halimous. Sign (private cult or private association?) - date unclear (SEG 21, 183; CGRN 73)}

This is a rule about offering cakes (the so-called bebdomos bous) placed on an altar of Hestia (Sokolowski). This falls into the category of signs. There is no indication of any authority.

\section{Epidaurus. Law or sign (sanctuary?) - fourth century BCE (SEG 16, 266; CGRN64)}

Instructions are given to the priest of Asklepios in the shrine of Apollo Maleatas to provide necessary items for sacrifice to a worshipper requiring them: crowns, barley, wood. The priests is to receive financial compensation for each of the items listed. Similar rules are also issued for the priest of Apollo. It is not clear who is issuing these rules - the sanctuary at Epidaurus is a possibility. There is no mention of any civic authority. This may fall into the category of sign, but it is quite lengthy and might instead be viewed as a law passed by the authorities responsible for the sanctuary. 


\section{Epidaurus. Law/decree (Achaean League) - between 229/8 and 225/4 BCE $\left(I G I^{2} 1,73\right)$}

A first fragment lists some nomographoi of the Achaeans, and was obviously an official document issued by the Achaean League. A second fragment contains a rule mentioning priests (?) of Asclepius, requiring sacrifice and leading a panegyris.

\section{Epidaurus. Law or sign (sanctuary?) - second century CE (IG $\left.I^{2} 1,45\right)$}

This fragment appears to be a law or it may be a sign. If the restorations are correct, the Hieromnamones try offenders, and if they do not, they are subject to a fine of one hundred drachmas (lines 4-8). There appear to be rewards for volunteer prosecutors (lines 7-8, 11-12). Those who throw refuse such as dung and dirt (?) are to be fined fifty drachmas (lines 8-11).

\section{Epidaurus. Law (sanctuary?) - second or third century CE (IG IV ${ }^{2}$ 1, 742)}

It is difficult to tell which authority issued the many fragments of these rules about daily observances (hemeresia hiera, as the only heading, line A1, clearly states) in the sanctuary. Again, as with several other documents from Epidaurus (see above nos. 22 and 24), it may well emanate from the authority of the sanctuary itself. Several of the local officials such as the priest of Asclepius and the pyrphoros are concerned by the daily rituals, such as lighting lamps, burning incense, performing small specific rituals, etc.

\section{Tiryns. Fragment of law/decree (?) (polis?) - sixth century BCE $($ SEG 11, 369)}

The text is very fragmentary, with not more than ten letters preserved in each line. Sokolowski believes that the rules pertain to a sacred building and compares LSAM 55 and LSS 51. The text does mention (not) opening something (line 4). It is difficult to determine which authority issued these rules, but we note the mention of the fragmentary phrase $\varepsilon \gamma \delta \alpha \mu o-$ in line 11, which might suggest a rule of the city or local community. 


\section{Argos. Law/decree (polis) - sixth century BCE (IGFGP 25 prints only lines 5-13)}

The text concerns property (possibly dedications if the restoration in line 4 is

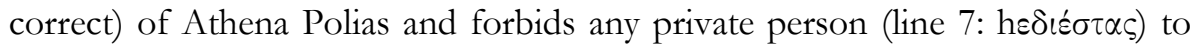
use these items outside the temple (lines 5-9). The state alone is to have control over the property of the goddess (lines 9-10). If anyone damages this property, he is to repair it, and the damiorgoi are to compel him to carry out the repairs (lines 11-12). The amphipolos is to oversee the activity (line 13). Because the text mentions public officials responsible for enforcing the rules and was headed by the names of six damiorgoi of Athena responsible for its enactment (line 1 and on the left side of lines 5-11), this must be a law/decree of the polis. Koerner provides a German translation of lines 5-13.

\section{Sparta. Law/decree (polis?) - sixth century BCE $(I G \mathrm{~V} 1,722)$}

Sokolowski reports Beattie's adventurous restoration and interpretation of lines 1-3 as a prohibition against women weaving garments not prescribed by the polianomos. Sokolowski also reports Beattie's interpretation of lines 3-5 as a prohibition against unmarried women serving as priestess, followed by an order for the pyrokoroi to purify the temple should this happen. The precise content of the rules and the authority behind them remain elusive.

\section{Sparta. Uncertain fragment (polis?) - second century CE (IG V 1, 1511 add.)}

Sokolowski believes that the text is a copy of an older regulation about the cult of Demeter. Not enough remains on the stone to draw any firm conclusions. Sokolowski restores the name of a female official ( $\theta$ oเv $\alpha \varrho] \mu o ́ \sigma \tau \varrho ı)$ in line 2; see LSCG 64 from Messene. Ritual supplies are mentioned in both fragments, and fr. B mentions priestesses and goddesses.

\section{Laconia. Thalamai. Dedication and sign (private individual) - fifth century BCE (IG V 1, 1316; Diakoumakou 2010-2013; CGRN11)}

The brief text is inscribed on a block of marble; the first line has the genitive $\Delta$ iò $K \alpha \beta \alpha$ ' $\alpha$, which according to Sokolowski shows that the block belongs to an altar dedicated at a place struck by lightning (Sokolowski compares notably 
IG II 2 4965, 4964, and 4998). Sokolowski speculates that the word in line 6 is the name of the person killed by lightning; Diakoumakou provides the correct reading of this personal name in lines 5-6 as Lesion son of Gaisulos. There is an order to sacrifice in line 4, and Sokolowski rightly argues that lines 2-3 indicate that the sacrifice should be penteteric (i.e. every four years). See Diakoumakou for a detailed study of the monument from which this block originates.

\section{Tegea. Law/decree (polis?) - fourth century BCE (IG V 2, 4; CGRN 65)}

The rules concern purification and ritual purity (lines 1, 14, and 17 and the restorations in line 9, 19 and 20), probably for a specific sanctuary; Apollo is mentioned in line 4. There are several officials mentioned (line 7: thearoi, priests, bieramnemon). There may be several clauses in the casuistic form (lines 6-7, 1819, 20-21).

\section{Arcadia. Excerpt of law/decree or sign? (polis) - fifth century BCE (SEG 11, 1112; IGFGP 35)}

The text is inscribed on a bronze tablet and contains a rule forbidding luxurious clothing worn during the rites of Demeter (line 1). Any such clothing is to be dedicated to Demeter Thesmophoros (line 2). If the offender does not dedicate the clothing, the offender is subject to a curse (lines 3-4), and the demiorgos is to impose a penalty of thirty drachmas (line 4). Sokolowski believes that lines 5-7 impose a penalty of thirty drachmas on the offender and a charge of asebeia. Koerner in IGFGP provides different restorations and believes that the penalty applies to the official who does not impose the fine and makes him polluted for ten years. Note the combination of a curse with a financial penalty. In any case, the presence of the public official in these rules must qualify them as a public document (which is specifically reckoned to be valid for ten years and also as sacred, cf. lines 6-7).

\section{Dyme (not Patras as in Sokolowski). Sign (polis?) - third century BCE (I.Patras 6; CGRN 127)}

Because of its brevity, this is a sign, which forbids women from wearing gold weighing more than an obol, an embroidered garment, a purple garment, wearing make-up, or playing a flute in the rituals of Demeter. If any of the rules is violated, the shrine is to be purified by the woman thereby deemed impious 
(parsebeousa); on impiety in ritual norms, see Delli Pizzi 2011. Cults of Demeter are usually public cults, but certainty in this case is impossible.

\section{Corinth. Sign (polis or private association) - around $475 \mathrm{BCE}$ (Corinth VIII 1, 22; LSAG $129+132$ no. 37)}

The text is found on a poros stele placed before an underground passage. In the first two lines the words hó@os hı®@ós have been restored; the sacred context however may be presumed from the first partly preserved word, asylos. There is a prohibition against going down into the underground structure (lines 4-5) with a penalty, probably in obols (lines 6-7).

\section{Oropos. Law/decree (polis) - fourth century BCE (I.Oropos 276)}

There appears to be an enactment formula starting at the end of the first line, but the left part of the stone has not been preserved. There appears to be a fee charged to those using the shrine (lines 3-6) and a rule about writing down the name and the city of each person who enters the shrine (lines 7-9).

\section{Akraiphia. Sign (polis or private association) - fifth century BCE}

The meaning of the word in the first line is not clear (for proposals see Sokolowski and cf. now e.g. SEG 31, 392), but lines 3-5 appear to contain an order in the imperative not to cut daphne. Sokolowski restores a clause about sacrificing a ram and a goat in the lines $5-7$, but the restoration is doubtful as only a few letters are visible on the stone.

\section{Delphi. Sign (polis?) - around 480-470 BCE (LSAG $102+104$ no. 16; CIDI 2)}

Sokolowski restores the phrase [oủ $\theta \varepsilon \dot{\mu} \iota \varsigma$ ] in the first line and (following Jeffery in $L S A G$ ) views the regulation as a prohibition on selling animal carcasses. Rougemont in CID is more cautious and views any sense as elusive. The inscription appears to come from the area of the Roman agora. 


\section{Delphi. Law (polis) - fifth century BCE (CID I 7; CGRN29)}

This is a law about theoriai from Andros to Delphi (CID I 7, line Aa6, not in Sokolowski; we follow the numbering of CID here). The enactment formula is missing. There are rules about possibly about housing (lines A4-5), offering or food (lines A6-11), perquisites for officials (lines A11-13), banquets (lines A1424), fees for rituals (lines A25-8) and the rights of people from Andros to skins of sacrificial animals (lines A28-33). A second fragment calls for the Council of Andros (this is about those "sailing" to Delphi) to elect five men and to administer an oath (lines B4-8) but not to receive food (lines B8-10). They have power to impose fines on the disorderly (lines B1-15) and must report the fines to the Council (lines B15-17). Given the Ionic dialect of the fragments, the law/regulation was very probably passed by the people Andros. Sokolowski follows his predecessors in calling this a "convention" with the Delphians, but it does not take the form of a treaty even though it may presuppose the existence of one. Rutherford (2013), 198-200 and 369-372 no. B3, accepts the usual designation "convention" for this type of document, while noting that this example only rarely reveals the participation of Delphi or its officials in the background of these decisions. By "convention", scholars appear to designate a form of bilateral agreement between a polity and the panhellenic sanctuary; see LSS 41 below for a clearer case of a treaty.

\section{Delphi. Law/decree (polis) - end of fifth or beginning of fourth century BCE (CID I 8; Choix Delphes 26)}

This starts with an enactment formula and was passed by the Delphians (line 1). It has rules about the tax or tariff (pelanos) to be paid by the Phaselitai, one for the "public," the other for private individuals. For a similar distinction between public and private see LSS no. 41. It also lists the names of two theoroi (lines 56) from Phaselis, and one archon (unknown, but probably from Delphi). See also now Rutherford (2013), 196 and 375, who follows Rougemont in CID (and earlier Homolle) in translating $\propto \varnothing \varepsilon \varepsilon$ as an adverb ("in this way") and not a verbal form. The alternative (Pouilloux, FD IV 369, and earlier Herzog et al.), which is favoured here, is to take $\propto \delta \varepsilon$ as a form of $\varepsilon^{\prime} / \alpha \delta \varepsilon$, indicating an enactment formula, thus pointing to a decree. Rutherford notably objects that the presence of the two theoroi from Phaselis as "witnesses" points to a "convention" or a form of agreement. Choix Delphes offers a balanced commentary and prefers to leave the matter unresolved. 


\section{Delphi. List of portions from sacrifices (unclear authority) - late fifth or early fourth century BCE (CID I 4-6; CGRN30)}

Sokolowski provides the text of three fragmentary inscriptions, which appear to contain regulations about the distribution of portions of victims. It is far from certain that the three inscriptions belong together, though all three in some ways relate to Athenian privileges and requirements during sacrificial procedures at Delphi. See now Rutherford (2013), 372-374 no. B4.

\section{Delphi. Treaty between Skiathos and Delphi - fourth century BCE (CID I 13; Choix Delphes 31)}

This is a treaty between the people of Skiathos and Delphi (lines 1-5). The people of Delphi grant to the people of Skiathos and the members of its colonies the privileges of promanteia and exemption from taxes except the pelanos (lines 5-8). The price of a public pelanos is one Aeginetan stater, the price of a private pelanos is two obols (lines 8-12). For the skin of a sacrificial animal, the price for the public one is two obols, for the private one obol (lines 12-15). There follows a regulation about payments \&̇i $\varphi \varrho u x \tau \omega$, but the meaning of the phrase is not clear. Amandry thought it refers to beans used in divination by lot; Sokolowski thought it refers to a victim which did not provide a skin (e.g. a pig) and compared the term in LSCG 24, line 6 and $L S A M$ 46, line 5; Rutherford, following Rougemont (and Vatin), thinks possibly of firewood.

Several lines are not preserved. The remaining part of the inscription pertains to the consultation of the oracle (lines 20-26), the provision of a room for banqueting, wood, wine, and salt (lines 28-29), portions at the Theoxenia (lines 29-31), priority in legal procedures and asylia (lines 29-34). The inscription ends with an enactment formula indicating that the Delphians have ratified these ancestral privileges for the people of Skiathos (lines 34-39).

For useful recent commentaries, see Choix Delphes and now Rutherford (2013), 196-200 and 378-379 no. C1.

\section{Delphi. By-law (private association) - fourth century or ca. $\mathbf{3 6 0}$ BCE (CID I 12; Choix Delphes 32)}

This is a by-law of the koinon of Asclepiadai from Cos and Cnidos and begins with an enactment formula (lines 1-3). Any member of the group who comes to Delphi and wishes to consult the oracle or to sacrifice must swear an oath that he or she is a member of the Asclepiadai by descent through the male line $\left(x \alpha \tau^{\prime}\right.$ 
$\dot{\alpha} \nu \delta \varrho o[\gamma \varepsilon v] \varepsilon \alpha \nu)$ (lines 4-11). After come some lines in which few letters are preserved and a gap. There is a clause forbidding anyone (of the members of the group) who violates the regulation to enter the area of the oracle with the privileges of the Asclepiadai, to benefit from any other privilege granted to the Asclepiadai from the Delphians (lines 14-23).

\section{Delphi. Law/decree of the Amphictyons - around 218 BCE (CID IV 85; Choix Delphes 118)}

This is a law/decree of the Amphictyons and begins (in Sokolowski) with an enactment formula (line 1); Sokolowski does not include the full preamble, listing officials. The regulation forbids anyone to place a dedication in the portico (pastas) dedicated by King Attalus, to set up a tent or to light a fire (lines 1-5). If anyone violates the rule, it is permitted to move the dedication, and the person who made the dedication is to pay a fine of one hundred staters (the amount is completely restored) sacred to Pythian Apollo (lines 5-7).

\section{Delphi. Law/decree of the Amphictyons - 160-159 BCE (FD III.3 328; Choix Delphes 167; CGRN 204)}

The background of this law/decree of the Amphictyony is a donation by Eumenes II of Pergamum to the people of Delphi (see also Choix Delphes 165166). The first five lines appear to be similar to those of the donation by Attalus II (LSCG 80). The festival includes a sacrifice of three cows, a procession and a public banquet. The officials are subject to review by the mastroi and subject to the penalties in the law of the mastroi (lines 1-5). The epimeletai are to sacrifice three cows to Apollo, Leto and Artemis and to distribute the meat and use the rest for the public feast with forty measures of wine (lines 5-8). On the eleventh of Herakleios the priests of Apollo and the other gods, the prytaneis, the archontes, the other officials and the lampadistai, ten from each tribe, are to prepare the sacrifice and on the twelfth to lead the procession (lines 8-12). If the leaders do not ensure good order at the festival, they are subject to a sacred fine of ten silver staters (line 11-13). The archons are to keep half and give half in their accounts (lines 13-14). If they cannot collect the fine, they are to write up the names on a public record as is provided by law (lines 14-15). The road of the race is to run from the gymnasium to the altar, and the victor is to light the fire for the ritual (lines 15-16). If when the leaders have recorded those of the legal age, anyone does not obey even though he can, he is subject to a fine by the hegemon and the other lampadistai (lines 16-18). If someone says that he is 
unable or too old, let him swear an oath, and let the leaders record another person (lines 18-19). The priests, when they lead the procession, are to say a prayer for the Eumeneia as required by law (lines 19-20). The victorious tribe in the torch race may take ten staters of silver for the sacrifice (lines 20-21). The members of the council in office are to inscribe the decree and place it next to the altar of Apollo and to send a copy to King Eumenes (lines 21-23). For this kind of donation to maintain or found a ritual or festival see Harris (2015), 7177.

\section{Olympia. Treaty/decree between Anactorium and Acarnanian koinon - after 217 BCE (Habicht 1957; IG IX 12, 583)}

The inscription contains an agreement between the Acarnanian koinon and the city of Anactorium about the cult of Apollo of Actium, which the Acarnanians wished to transform into a federal sanctuary, or at any rate to formalise existing practices concerning this sanctuary (see below). The agreement is dated by the names of several officials (lines 1-6). The agreement then describes the circumstances that led to the agreement and names the officials sent as ambassadors to the city of Anactorium (lines 6-26). There follow the terms of the agreement. The Acarnanians will take responsibility for repairing the shrine and spending the same amount of money on contests, sacrifices, and panegyreis as was previously spent (lines 27-30). On panegyreis at festivals and their economic role, see de Ligt and de Neeve (1988). There are clauses about hiring musicians for festivals (lines 30-31), the revenues from the one-fiftieth import/export tax, other taxes at the panegyris, and the tax from the sale of slaves to be shared by the people of Anactorium and the Acarnanians (lines 3134), the appointment of four pentakologoi and four secretaries from both communities and agoranomoi from the Acarnanians, one from each city (lines 3436); dedications acquired by the Anactorians before the agreement are to belong to them, those made afterwards are to belong to the Acarnanians (lines 36-38). According to Habicht, there is a clause about hotels for those visiting the shrine (lines 38-41). A fragmentary clause pertains to the procession (lines 41-43). The people of Anactorium are to have control of the harbors and all tolls from them except at the panegyris (lines 43-45). The Acarnanians are to hold the contests at Actium each year unless war or an army camp makes it impossible; in this case the panegyris is to be held at Anactorium itself (lines 4550). If the Acarnanians do not carry out what is written, the shrine is to revert to the ownership of the Anactorians (lines 50-52). There follows a decree of praise for the people of Anactorium by the Council and koinon of the 
Acarnanians and a promise to make the shrine prosper jointly as a way of demonstrating piety to the gods and loyalty to ancestors (lines 52-58). The Acarnanians order their treasurers and officials to spend money only on the repair of the temple and the dedications (lines 58-61). The decree and the agreement are to be inscribed and placed in Actium and in Olympia respectively (lines 61-67; only the latter copy is preserved). The preserved portion of the inscription ends with an entrenchment clause and a provision allowing modifications that do not alter what is written in the laws (lines 70-77).

\section{Eretria. Law/decree (polis) - end of fourth century BCE (IG XII 9, 192; see also $S E G 40,758)$}

This is a law/decree of the polis, which begins with the name of a priest and the names of three polemarchs, who are the proposers of the regulation (lines 1-3). The regulation mentions that the community has recently been liberated and regained its democracy, and wishes to establish a memorial for the day of freedom (lines 3-6). There follows an enactment formula and the order for all people of Eretria and foreign residents to wear an ivy crown at the procession of Dionysus (lines 6-8). If the restorations are correct, the treasurer is to pay for the crowns to be made. Other particulars concerning the procession followed in the fragment (lines 10-11).

\section{Andros. Decree of the Council - first century BCE (IG XII 5, 721, with add. p. 336)}

The first part of the inscription is missing, but the preamble of the decree refers to the temporary sale (literally here "renting") of a priesthood. Sokolowski believes that is it a measure to replace a priesthood which was previously held by someone else. There is an enactment formula in line 11, which introduces a substantial fragment of the considerations of an honorific decree for the individual concerned. This is not included by Sokolowski, who only takes into consideration lines 1-11, part of the preamble of the document.

\section{Tenos. By-law (private association) - fourth century BCE (IG XII Suppl. 303; R\&O 61)}

This is a by-law, entitled "law of introduction", enacted by a private group on Tenos, which may have resembled a phratry at Athens. It contains regulations about the introduction of new members (line 1). A wife should sacrifice a 
young goat, and so should a son (line 1). No one is to be introduced until the father is fifty years old (lines 1-2). The restoration and meaning of lines 2-3 must remain uncertain. It is forbidden to introduce a nothos (line 4). Whoever introduces a nothos is to pay a fine of twenty-five drachmas (lines 5-6). Sokolowski, followed by Rhodes and Osborne, believes that it is possible to introduce a nothos if a fine is paid, but this makes no sense because a fine is imposed on someone who violates a rule and is a means of enforcing it. The restoration and interpretation of the end of line 4 and the beginning of line 5 remains unclear. Each person who swears should present two witnesses (line 57). The person who introduces must swear that he is a brother of the same father or the son of a brother (lines 7-8). The mother should also swear (line 8). Whoever does not persuade those present must pay a fine of five drachmas (lines 8-9). For some discussion, see Ogden (1996), 286; for rules concerning bastards, compare also LSCG 177, lines 46-49.

\section{Delos. Sign (polis?) - fifth century BCE (ID 68)}

This is a sign inscribed on a marble lintel in the temple of Apollo Archegetes on Delos. The sign forbids foreigners from entering. Sokolowski compares Syll. ${ }^{3}$ 1024, Hdt. 5.72, 6.81, and 8.134 and LSCG 96, line 26.

\section{Delos. Sign (polis?) - fifth century BCE (ID 69)}

This is a sign containing a rule against washing anything in the fountain, bathing in the fountain, or throwing anything else (dung?) (lines 1-5). There is a sacred penalty of two drachmas (lines 5-6). The fountain of Minoe was a public/sacred fountain. For a comparable regulation concerning the Inopos 'reservoir', see SEG 56, 950. See also above no. 4.

\section{Delos. Law/decree (polis) - third or second century BCE (IG XI 4, 1030)}

This is a decree of the Council and assembly of Delos concerning the protection of the sacred buildings (oikiar) and the hestiatoria (dining halls) in the sanctuary. Disorderly conduct appears to be proscribed (lines 3-4) as well as sleeping or perhaps camping in certain locales (lines 6-7 etc). The sanctions and penalties imposed on such behavior are not preserved. 


\section{Delos. Law/decree (polis) - first quarter of the second century BCE $(I G$ XI 4, 1032)}

The inscription is written on two heavily damaged fragments of a stele and begins with an enactment clause (line A1 partially restored), the name of a proposer (line A2), a motivation clause (lines A3-5), and another enactment clause (lines A5-6). The law/decree describes the perquisites of the neokoros (lines B1-9). There follows a publication clause with an order to place the stele in the Asclepieion (?) (lines B10-15). The final section may concern the appointment of the neokoros (lines B15-21; cf. line B6, which implies appointment by lot).

\section{Delos. Law/decree (polis) - end of the third century BCE (SEG 23, 498)}

The inscription begins with an enactment clause (line 1) and the name of the proposer (lines 2-3). There follows a motivation clause, which states that the aim of the law/decree is to keep the area in front of the sanctuary of Dionysos clean/pure (lines 3-9). There follows another enactment clause (lines 9-10), which is followed by a clause in the casuistic form allowing anyone who catches a person violating the decree to arrest and denounce the offender to the Council (lines 10-13), which has the power to administer fifty lashes to a slave and to impose a fine of ten drachmas on a free person and to collect the money. For the penalty of fifty lashes for slaves compare SEG 26, 72 with Stroud (1974), 178. The amount of the fine is to be given half to the bieropoioi and half to the person who denounces the offense (lines 13-20). The final part of the inscription contains a publication order, payment for the stele, and the name of the proposer (lines 20-25).

\section{Delos. Sign (sanctuary or private association) - end of second century BCE (ID 2530; CGRN217)}

The text was found in the temple of the Syrian goddesses and provides regulations about purity. Worshippers are to enter three days after consuming fish (lines 1-3), washing after consuming pork (lines 3-4), three days after (intercourse with) a woman (line 4), seven days after giving birth (line 5), forty days after abortion or miscarriage (lines 6-7), and nine days after menstruation (lines 7-9). Sokolowski provides parallels for all these types of pollution; see also CGRN. 


\section{Delos. Sign (private dedication) - second century BCE (ID 2305; CGRN 171)}

The inscription is written on an altar dedicated by Damon of Ascalon to Zeus Ourios, Astarte, and Aphrodite Ourania in gratitude for being saved from pirates. Sokolowski does not print the dedication and only the prohibition, which forbids the introduction of a goat, a pig and a cow. Sokolowski states that the people of Ascalon did not sacrifice goats to Zeus and pigs and cows to Astarte and Aphrodite. He notes that the prohibition against sacrificing cows is not attested in Greek sacred regulations.

\section{Delos. Sign (private association or sanctuary) - second century BCE (ID 2180; CGRN172)}

The inscription contains a dedication and a prohibition, but Sokolowski prints only the latter. The dedication is made to Theos Megas, Tachnepsis (Isis), and Zeus Kasios. The rule prohibits women from entering and men from entering in woolen garments because one wore linen garments in Egyptian rites (see Sokolowski). Many cults of Egyptian gods on Delos were the prerogative of private associations, such as this example from Sarapieion A, though public sanctuaries (viz. Sarapieion C) also existed.

\section{Delos. Sign (private association) - second century BCE (ID 2308; CGRN 174)}

This is a dedication to Heracles and Hauronas, two gods who protected Iamnia, a small village on the coast of Palestine. The base was set up by Zenodorus, Patron, and Diodotus from Iamnia for the benefit of themselves, their relatives and the citizens (perhaps native Iamnitai who gathered together in a cult association). The regulation calls for sacrifice except that of a goat.

\section{Delos. Sign (private dedication) - around 100 BCE (ID 1720; CGRN216)}

This is similar to no. 55. The text is inscribed on an altar dedicated to Poseidon of Ascalon and forbids the sacrifice of pigs and goats. 


\section{Delos. Law/decree or sign (polis?) - Roman period (ID 2529)}

The first eighteen lines of the inscription are not well preserved with the left side of this part missing. The regulations concern the ritual purity required for entry into the shrine of Zeus Kynthios and Athena Kynthia, and Sokolowski restores the names of two public sacred offices in lines 4-6. The rules require purity of hands and soul (lines 13-14), white clothes, no shoes, to be pure "from woman" and from meat (lines 14-16). Those entering should carry neither a key nor a ring of iron, neither a belt nor a ballantion (a pouch, or more probably a javelin), nor arms, nor any other forbidden item during sacrifices (lines 17-25). This would appear to be a sign placed near the entry to a shrine. Sokolowski compares LSS 91, but see also immediately below no. 60 .

\section{Minoa on Amorgos. Sign / excerpt of a law/decree (polis?) - fifth or fourth century BCE}

The inscription is written on both sides of a stele. The regulation (nomos, line A4) forbids anyone to bring an iron instrument (i.e. a weapon) into the temple (lines A1-2). Anyone who does is subject to a penalty (lines A2-3). If the restorations in lines 4-6 are correct, half of the fine goes to the person who reports the offense. The other side repeats the prohibition of arms, but appears to name the god of the temple, Delian Apollo (lines B1-3).

\section{Aigiale. Law/decree (polis) - end of the second century BCE (IG XII 7, 515)}

This is a law about a festival of the polis created by the donation of Critolaus in memory of his son Aleximachus, who was heroised. The first part of the inscription is not printed by Sokolowski in $L S S$, but concerns the financial measures about the donation of Critolaus to raise money for the festival (lines 1-39). The first clause abut the feast instructs the prytaneis each year in the month of Apaturion to elect two epimeletai who are at least thirty years old (lines 40-42). From the money provided, the epimeletai are to purchase a cow above not less than two years old and to sacrifice it (lines 42-45). The prytaneis and the gymnasiarch and the ephebes are to lead the cow from the Prytaneion. The younger men are to follow; if not, the gymnasiarch is to compel them (lines 4549). The epimeletai are responsible for the feast (lines 49-51). The epimenioi are to provide anything else needed. Citizens, foreigners, paroikoi and Romans who are present are to receive meat except the children (lines 51-59). The epimeletai are 
to provide the feast free of cost in the gymnasium; they are to sell the hides immediately and spend the money there (lines 59-63). The epimeletai are to give each ephebe a mna of meat, which is not to be taken away from the triclinium (lines 63-65). The epimeletai are to purchase nine metretes of wine (lines 65-68).

Epimeletai are to provide tragemata on both days and to carry out the feast in the gymnasium (lines 68-70). The epimeletai are to buy barley and to give a choinix to male citizens, paroikoi, foreigners and Romans and half a choinix to boys (lines 70-74). For the contest to take place, the epimeletai are to slaughter a ram at daybreak in front of the statue of Aleximachus that Critolaus would set up (lines 74-76). There follows a rule about an offering to be placed before the statue and about the contest (lines 76-81). On sacrifices at the erection of a statue see Sokolowski's commentary. The epimeletai are to provide prizes for contests according to the gymnasiarchic law (lines 81-83). There is to be no contest for the pankration, but Aleximachus is to be announced de facto the victor (lines 83-84). The gymnasiarch is to make sure the torch-race of the boys and of the men is held and to compel all the men younger than the stipulated age to run in the race (lines 84-86). For a detailed study, see Gauthier (1980).

\section{Paros. Sign (private association or familial cult?) - sixth or fifth century BCE (IG XII 5, 1027; CGRN9)}

The sign is on an altar for Zeus Elasteros (the epithet is almost completely restored) set up by "those from Mandrothemios," which would suggest a family group or a private association. Honey is to be given as a libation. See Sokolowski and now CGRN (based on the thorough study of Matthaiou [19921998]) for interpretations of the epithet.

\section{Thasos. Sign (polis?) - around 440 BCE (IG XII Suppl. 414; CGRN27)}

This is a sign forbidding the offering of a goat or a pig to Thasian Heracles, who had a public shrine in the city (lines 1-2). Women are also not allowed (lines 2-3). According to Sokolowski, three types of "taxes" are prohibited: 1) payment of one-ninth to the sanctuary, 2) payment to the priest who officiates, and 3) portions that should serve as prizes at contests. The regulation does not concern taxes, but rather the particularities of sacrificial practice in the cult of Herakles on the agora of Thasos; see CGRN. For a recent study, see Pitz (2016), with further references. 


\section{Thasos. Law/decree (polis) - fourth century BCE, possibly 360-350 BCE}

Only one fragment of this law/decree was available for Sokolowski. In 2007 Fournier and Hamon published a second fragment and provided a new edition of the first fragment. We follow their numbers and text. The prescript is generally missing, but is now partly attested in a further fragment of the stele published by Hamon (2010), which evokes the polemarchoi, the Council and very probably the demos. The first preserved clause orders the agoranomoi to neglect nothing on the day of the procession to the public cemetery before the procession begins (lines 1-2). No one is permitted to mourn for the agathoi (those who died in battle) for more than five days; no one is allowed to hold private mourning (lines 3-4). If anyone violates these rules, the violation is "on

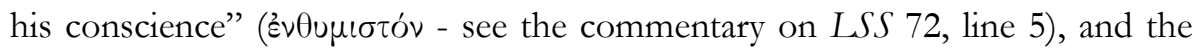
gynaikonomoi, the archons and the polemarchs are to prevent this and can impose the fines permitted by law (lines 4-7). The polemarchs and the Council are to inscribe the names with patronyms on the list of the agathoi, and their fathers and sons are to be invited to dinner when the city performs sacrifices (lines 7-11). The apodektes is to give each a sum equal to those given to timochoi (lines 11-12). Fathers and sons are to have places of honor at contests (lines 1213). The organizer is responsible for providing them places (lines 13-16). All the children of the agathoi are to receive greaves, breastplate, sword, helmet, shield and a spear, all of which will not be less than three mnai (lines 16-20). The arms are to be presented at the Herakleia (lines 20-22). There is a fragmentary clause about daughters at age fourteen. This is possibly about public contribution toward a dowry (lines 21-22). If any of the children of the agathoi are destitute, they are to make an application, and the archontes and the apologoi are to evaluate their case (lines 27-29). The prytaneis are to introduce them and propose not more than four obols. The payment is to be made by the apodektes (lines 29-31). If any metic dies in war, he is to receive seventeen and a half staters from the apodektes (lines 32-34). The decree is to take effect in the archonship of Bion and to apply for fathers who have died in the war bravely and do not have anything from the provisions of the (earlier?) decree (lines 3438). There is a publication clause instructing the secretary of the Council to inscribe the decree on a stele and to place it in front of the prytaneum; payment is to be given by the apodektes (lines 38-41). Anyone who violates one of the regulations is subject to a lawsuit and a penalty of $(1,000$ ?) staters (lines 42-46). Fournier and Hamon restore a reference to a volunteer accuser, who receives half of the penalty (lines 44-46). 
Sokolowski appears to have included these regulations as a loi sacrée, but only the provisions in lines 1-7 pertain directly to religious practices. The rest of the provisions concern the rights of those fallen in battle and their fathers and children. This inscription would therefore fall into the category of laws and decrees of the polis that primarily concern non-religious activities, but contain some clauses about religious matters. For this category see Harris (2015), 66-67.

\section{Thasos - Fragment (uncertain authority) - fourth century BCE (CGRN 68)}

This fragment may come from a larger regulation or a smaller sign. It makes an appeal to themis (line 2) and appears to be concerned with ritual procedures (libation to Zeus Katharsios) and closely related purifications (use of sulfur as a purificatory agent, perhaps washing from the head down if the restoration in the final lines is correct).

\section{Thasos. Fragment (uncertain authority) - fourth century BCE (CGRN 48)}

A very fragmentary text of uncertain character, though mentioning some ritual elements. Line 4, as restored in Sokolowski, may mention a rule of the ou themis type.

\section{Thasos. Sign (polis or private association?) - fourth century BCE (CGRN 67)}

If the restorations are correct-which is far from certain-the regulation appears to require the sacrifice of an ox or a goat to Dionysus, but allows private individuals to sacrifice whatever they wish.

\section{Thasos. Sign (uncertain authority) - fourth century BCE}

This was found on an altar for libations in a temple of Dionysus. The text is heavily restored to give a regulation allowing libations to Agathos Daimon, but not the Agathe Tyche. See Sokolowski for various views. 


\section{Thasos. Excerpt (?) of a law / decree (polis) - end of the fourth century BCE}

This appears to come from a law prohibiting certain judicial procedures such as denunciation (endeiknuein) and arrest (apagein) during the festivals listed (lines 13). Sokolowski does not include 2 further lines, which also contain interdictions of judicial procedures during the festival days in question as well as when the emmena (monthly judgements) take place; line 5 mentions an official called epistates. The regulation is similar to ones at Athens forbidding creditors to seize debtors during the Dionysia and the Eleusinian Mysteries (Dem. 21.11-12, 175 with Harris in Canevaro [2013a], 216-224), but it also seems to have a wider application to polis procedure. The larger document from which this perhaps was excerpted may have fallen into the category of laws/decrees that contain some rules about sacred matters but are not primarily concerned with religion, on which see Harris (2015), 65-67.

\section{Thasos. Fragment (uncertain authority) - end of the fourth century or early third century BCE (CGRN69)}

The regulation appears to contain a list of portions involved in the sacrifices to Dionysus, but is too fragmentary to permit any definitive conclusion about its character.

\section{Thasos. By-law (private association) - second century BCE}

This is a by-law of the Sarapiastai and starts with an enactment formula (line 2) and a motion of praise (lines 3-4). The terms of the sale of the eponymous priesthood with the perquisites are given: the priest will wear a white strophion and crown at each meeting with a proclamation by the bierokeryx and serve for life (lines 14-17). He will have equal honour at the banquets (lines 17-20). Payments will be made at fixed intervals (lines 21-27). It is the responsibility of the eponymous priest and the secretary to publish the decisions of the group in the shrine and the names of the person who holds the priesthood and the members (lines 27-36). The final part records that Hypsicles the son of Stasimenos has purchased the priesthood for ninety-six drachmas (lines 37-39). A list of the names of the members of the association also followed, but is not included by Sokolowski. 


\section{Thasos. Sign (polis) - first century BCE}

This is a sign for a cult of Theogenes, who is known from literary sources (Pausanias 6.6.5-6; 6.11; Dio Chrys. 21.96; Suidas s.v. Nıxĩv; Lucian Hist. 35; Deorum Conc. 12). For a dedication at Delphi see Syll. ${ }^{3}$ 36. The sign is inscribed on a money-box (thesauros; cf. e.g. now the prescriptive thesauros of Aphrodite Ourania from Athens, SEG 41, 182, early fourth century BCE; on sacrificial tariffs and thesauroi, cf. the discussion in Lupu, NGSL, p. 59-60). The regulations order those sacrificing to Theogenes to give an aparche of not less than one obol into the thesauros (lines 1-3). The person who does not contribute an aparche is to have the offense on his conscience (enthumiston, lines 3-5). The money collected is to be given to the bieromnemon each year (lines 5-7), who is to keep it until the amount reaches one thousand drachmas (lines 8-9). When this amount is collected, the Council and Assembly are to determine how the money is to be spent, either for an offering or for equipment consecrated to Theogenes (lines 9-14).

\section{Thasos. Sign (polis or private association?) - second century BCE (IG XII Suppl. 394; CGRN178)}

This is a sign prohibiting the sacrifice of a goat or a pig to Peitho. It is not possible to determine whether this is a public or a private cult, though the former is likely given the context in the city of Thasos.

\section{Thasos. Sign (polis?) - second century BCE, but reinscribed from an earlier text (IG XII Suppl. 409; CGRN23)}

This is a sign forbidding the sacrifice of a goat to Hera Epilimenie. It is not absolutely known whether this is a public or private cult, but the former is likely given that Hera was "the patron of the port" (Epilimenie) in this case.

\section{Samothrace. Sign (polis or sanctuary?) - first century BCE (SEG 12, 395; Dimitrova 2008: 239-240 no. 168)}

This is a sign forbidding entry to the shrine for those not initiated. There is no indication of the authority, penalty or officials, but the mysteries at Samothrace were a public cult, and this may be a sign set up by the polis. For a similar, though bilingual (Latin and Greek), boundary inscription from the sanctuary, see below no. 75 a. 


\section{5a. Samothrace. Sign (polis or sanctuary?) - first century BCE (Dimitrova 2008: 240-241 no. 169).}

A similar boundary stone to the one above (no. 75), inscribed with an interdiction first in Latin and then in Greek.

\section{Chios. Fragment (polis?) - fourth century BCE (SEG 22, 501; CGRN66)}

The fragments of this inscription appear to pertain to the perquisites of a priest. If the restorations at lines 14-15 are correct, then the citizens of Chios may be mentioned and this would suggest that a public cult is the subject of the document; cp. no. 77 below. See CGRN for further commentary.

\section{Chios. Law/decree (polis) - early fourth century BCE (CGRN 49)}

This is a regulation of the polis (see lines 10-11) about the sale of a priesthood. The person who purchases the priesthood is to serve for life and is to enjoy freedom from taxes (as long as he is in the city?) (lines 1-3). The perquisites are given in lines 4-10. If the polis holds a feast, the priest is to receive a hemiekton of gold (lines 10-12). The last preserved clause relates to a sacrifice and a feast put on by a xenos; in this case, the same will apply as in the case of a citizen of Chios, with additional requirements now missing in the fragment below.

\section{Chios. Sale of a priesthood (polis?) - second century BCE (CGRN 170)}

This records the purchase of a priesthood by Daphnaios (lines 1-4) and briefly records his perquisites, which are similar to those in the previous inscription (lines 4-8). The transaction is dated by the prytanis of the city.

\section{Chios. Sign (polis or private association?) - fourth century BCE (CGRN 51)}

This is a sign with an order not to bring wine into the sanctuary of the Fates and of Zeus, leader of the Moirai. On wineless offerings add Henrichs (1983) to the sources and bibliography cited by Sokolowski; see also now CGRN. 


\section{Samos. Sign (sanctuary?) - ca. 350 BCE (IG XII 6, 260; CGRN 87)}

The inscription is fragmentary but appears to be a sign indicating the number and kind of offerings-primarily breads or cakes-to be made to Kourotrophos, Hermes, Artemis and Apollo.

\section{Samos. Law/decree (polis?) - first century CE}

This fragmentary inscription contains a number of regulations about the protection of a grove sacred to Hera and may contain clauses in a casuistic form imposing a penalty of one hundred drachmas for each tree cut down (lines 9-13). There may be a reference to a lawcourt in line 13.

\section{Mytilene. Sign (?) - late hellenistic period (IG XII Suppl. 23)}

This is a sign urging worshippers to enter the sanctuary pure and "thinking holy thoughts". It is not known whether this belongs to a private or public sanctuary. On purity of mind, see now Petrovic and Petrovic (2016), esp. 280288 for this type of inscribed regulation concerning entry into the sanctuary.

\section{Astypalaia. Law/decree (polis) - second or first century BCE}

This is a law/decree of the polis, which begins with an enactment formula (lines 1-2) and modifies previous regulations (lines 3-4). The aim of the regulation is to ensure that everything for those who march in the procession for Dionysus in the month of Iobacchios be done to honor the god and that all animals be sacrificed according to the traditional rules (lines 4-10). Anyone who violates the rules is to be cursed, and the prytaneis are to impose a fine up to the amount they are permitted or to lead them to the Council (lines 10-14). The Council is to impose a fine up to the amount they are permitted (lines 14-15). A man is to be elected (lines 15-18) to mark with an iron brand the animals to be sacrificed for the procession when the bieropoioi approve the animals (for the dokimasia of sacrificial animals see Gauthier [1984] and Feyel [2009], 303-334). If the restoration is correct, the brand is to remain in the shrine of Dionysus (lines 1819). Sokolowski believes that the branding was done so that no one sacrificed the animals after the festival or outside the sanctuary. Alternatively, the branding was done to indicate that the animals had been approved for sacrifice by the bieropoioi. Compare LSCG 65, lines 70-71. 


\section{Calymna. Fragment (uncertain authority) - first century BCE (GIBM II 300)}

The inscription is too fragmentary to permit analysis.

\section{Rhodes. Lindos. Law/decree (polis) - fifth century BCE (SEG 4, 171; IGFGP 56; Gonzales 2008)}

This is a law/decree of the polis, which starts with an enactment clause (lines 15 ) and concerns the funding of rituals for Enyalius, a god of war. Anyone who goes on a military expedition either public or private must pay one sixtieth of his wages (lines 5-10). The general is to collect the money for public expeditions and give it to the priest (lines 10-13). Private individuals are to give their money to the priest (lines 13-16). The priest is to disclose the amount to the Council and to hand it over to the priest who takes office in the following year (lines 16-20). For religious officials of the polis serving for one year see Harris (2015), 68-69. The epistatai are to write what the generals themselves have and the remainder, for those who go on expeditions (lines 20-24). The prytaneis serving in the relevant semester are to make sacrifices to Enyalius in the month of Artamitios (lines 24-28). A boar, a dog and a kid are to be sacrificed (lines 28-30). The clause in line 30-32 is not well preserved. The Council is to send the procession (lines 32-33). The hoplites are to follow the priests, as many as the Council appoints (lines 32-36). A cultic building for Enyalius is to be constructed when there is enough money; the Council is to collect the money (?) (lines 36-40). If the generals do not collect the money from the soldiers, this is to be reckoned an impiety toward the god, and he is to be subject to prosecution (lines 41-46). The same is true for those who go on private expeditions (lines 46-47). These clauses imply accountability and punishment, but do not indicate who is to discipline the offenders or the legal procedure (cf. Koerner: "nichts über das Verfahren ausgesagt wird"). The generals and the private individuals are to pay the money to the priest in the month when they return (lines 48-53). The regulation ends with a publication formula, setting up the stele near an existing altar of Enyalios (lines 53-59). For a new edition, with extensive commentary, see Gonzales (2008).

\section{Rhodes. Lindos. Sign (private individual) - around $200 \mathrm{CE}$}

The regulation is metrical and concerns a tax to be paid to Psithyros. Seleukos set up the temple to Psithyros and adorned it as the oracle indicated (lines 1-2). 
The oracle also ordered sacrifices and to pay not less than a drachma and to use this every year for offerings inside the temple of Athena (lines 3-5). The text concludes with a blessing: a promised of good actions to those who sacrifice (line 6). This is a regulation for a cult or shrine dedicated by a private individual on the authority of an oracle.

\section{Rhodes. Lindos. Extract of a calendar / sign (polis) - second century BCE (Lindos II 181-182; CGRN 179)}

These are two extracts from a civic calendar about sacrifices to Demeter, probably posted in front of the altar or the shrine of Demeter. There appears to be a different date on each stele ( $7^{\text {th }}$ Sminthios in line A1, and $12^{\text {th }}$ Sminthios in line B1). The name of the public priest, the bierotbytas, is partially preserved in each extract (lines A4 and B3).

\section{Rhodes. Lindos. Extract of a calendar / sign (polis) - end of the fifth century BCE (CGRN62)}

These appear to be extracts from a civic calendar about sacrifices for Athena Apotropaia and Zeus Apotropaios and name a public priest (archierothytas - lines A2-3, B 4). Women are prohibited from participating (lines A5 and B6).

\section{Rhodes. Lindos. Extract of a calendar / sign (subdivision of the polis) - fourth century BCE (Lindos II 26; CGRN63)}

This appears to be an extract from the official calendar, though it concerns a subdivision of Lindos. A goat is to be sacrificed by the official priest (bierothytas - on this office see Fraser and Bean [1954],124) of the local community of the Aigelioi. Women are not allowed to participate.

\section{Rhodes. Lindos. Law/decree containing orders to raise funds for cults (polis) - 22 CE (Lindos II 419)}

This inscription starts with a dating formula (lines 3-4) and has enactment formulas (lines 4, 10-11, 33). There has been a shortage of funds for religious activities (lines 5-7), and the people of Lindos have decided to raise money (lines 7-10). There is a publication formula at the end (lines 131-137). The decree calls for the election of five men who have been priests to receive 
bronze and iron objects from the priest of Athena and to sell them, then to turn the proceeds over to the priest (lines 18-30). Their names are listed at the end (lines 142-47). The second measure is to sell the right to have one's name written on statue bases on which the dedicator's name has become illegible and to move the dedication with the people's agreement (lines 30-44). The third is an invitation for donations (epidosis) (lines 44-75); on epidosis see Migeotte (1992), 121-126. A large section (lines 75-100 and probably beyond in several highly fragmentary lines) also concerns rules relating to the parakatatheka, the deposit of sacred money. There are several penalty clauses (cf. notably lines 119-131), and in some cases, violations of the provisions are called asebeia (carrying statues away, not collecting money, and an infraction that is not preserved) (lines 40-43, 86-92, 117-19). This is essentially a series of temporary orders to provide funds for the sanctuary; however, it can qualify as a law: the rules are presented as durable, applying in relative permanence to all priests in succession (interestingly the stele was eventually reused a few centuries later; cf. no. below).

\section{Rhodes. Lindos. Sign (polis or sanctuary?) - third century CE (Lindos II 487; Petrovic and Petrovic 2018)}

This is a detailed sign containing purity rules. It appears to collect a variety of material relating to the purity necessary for entry into the shrine of Athena in Lindos (inside the perirrhanteria and the [gates] of the temple, see line 2): lines 25 discuss general behaviour of the visitor and purity of mind (on which, see above, no. 82); lines 6-10 treat dress and clothing; lines 11-18 list more conventional abstentions from sources of impurity, followed by the number of days required in each case; lines 19-22 conclude these lists with general categories of the impure and the pure: criminals (those commit paranoma) are never pure, while sacred officials are also considered pure from involuntary offenses. The text concludes with a short epigram again on the subject of purity (lines 23-26). For a new edition, with detailed commentary, see Petrovic and Petrovic (2018). For the difference between serious offenses causing pollution that cannot be removed by purification, and involuntary offenses causing pollution that can be removed by purification see Harris (2015b). 


\section{Rhodes. Ialysos. Extract of a calendar / sign (deme) - around 200 BCE (Lindos II 680; CGRN 154)}

This is an extract of the (civic and official?) calendar about the sacrifice of a goat to Artemis, but it specifically concerns the deme of Pontoreis, which was part of the territory of Ialysos.

\section{Rhodes. Ialysos. Sign (uncertain authority) - second century BCE (CGRN 180)}

This appears to be a sign; it is again an excerpt from an originally longer

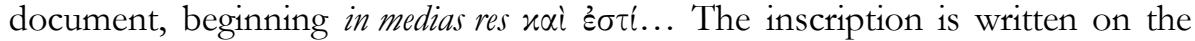
base of a statue, which was previously part of an altar or another structure. It would therefore belong to the category of signs written on altars or cult-tables with regulations about offerings. It may pertain to the perquisites of priests or to the portions due to the god.

\section{Rhodes. Camiros. Extract of a calendar / sign (polis) - third century BCE (T.Cam. 153; CGRN130)}

This appears to be an extract of the calendar concerning sacrifices to Poseidon and mentioning two different dates, one of which is the civic festival of the Hippokathesia (lines 8-11). The official priest of Poseidon is to perform both of the sacrifices (lines 7 and 12-13). The last clause requires that the meat be consumed at the place (lines 13-14).

\section{Rhodes. Camiros. Extract of a calendar / sign (polis?) - first century BCE (Lindos II 671; CGRN149)}

This appears to be an extract from a calendar used as a sign, ordering the sacrifice of a pregnant sheep on the fourth of the month Sminthios (Zminthios) to the Damateres, who appear to be the goddesses Demeter and Kore. As there are no other elements specified in the sign, whether it belongs to the civic calendar remains somewhat unclear, but is likely due to comparisons with nos. 94, above, and 96ff. below. 


\section{Rhodes. Camiros. Extract of a calendar / sign (polis) - third century BCE (T.Cam. 148; CGRN 109)}

This is an extract from the civic calendar, since it mentions public sacrifices. At a specific date, the priest is to sacrifice a lamb to Athena Polias, a civic cult (lines 1-3); at another, the priestess is to sacrifice a lamb (lines 3-5). The next clause has an order for a group of girls (anthesterides) to sacrifice a lamb on the same occasion (lines 5-6). Two further sacrifices appear to be preserved as part of this extract posted as a sign (lines 7-9 and line 10).

\section{Rhodes. Camiros. Extract of a calendar / sign (polis) - third century BCE (T.Cam. 152; CGRN110)}

This sign is similar to the previous inscription and appears to contain extracts from the civic calendar, with at least three different dates for sacrifices to Helios. For the second (lines 3-5), and perhaps the first too (lines 1-3), the damiorgos is to perform the sacrifices; this was the principal sacred and political official at Camiros. In another case, the hieropoioi are to sacrifice three goats to the god (lines 6-9). According to Sokolowski, the cult of Helios was a public cult; indeed, the public officials mentioned make this clear.

\section{Rhodes. Camiros. Sign (civic subdivision or private association?) - second century BCE (Lindos II 677; CGRN 153)}

This is a sign starting with a name in the genitive, probably of the hero or deity concerned (Maıvé@ou). According to Sokolowski, the genitive indicates that the sign comes from an altar or a shrine belonging to an association or family group. Following the suggestion of Blinkenberg, the group could be identified as the Mainyridai known from T.Cam. 112a (see CGRN for further commentary).

\section{Rhodes. Camiros. Extract of a calendar / sign (polis?) - third century BCE (T.Cam. 149; CGRN 111)}

This fragmentary inscription appears to be a similar extract from the calendar (see, inter alia, nos. 94-97 above), mentioning at least two dates. 
100. Rhodes. Camiros. Extract of a calendar / sign (polis) - third century BCE (T.Cam. 150; CGRN112)

This fragmentary inscription appears to be an extract from the calendar, similar to nos. 94-97 above. There is a date mentioned (lines 1-2), and an order to the bieropoioi to sacrifice to Pheme (lines 2-5); these were public sacred officials at Camiros.

101. Rhodes. Camiros. Extract of a calendar / sign (polis) - third century BCE (T.Cam. 151; CGRN113)

This inscription appears to fall into the same category as nos. 94-97 above and the immediately preceding items. The priest of Dionysus (lines 6-7), almost certainly belonging to a public cult, is to make sacrifices on two separate occasions to the Muses and to Mnemosyne.

102. Rhodes. Camiros. Extract of a calendar / sign (polis) - third century BCE (T.Cam. 155; CGRN114)

This fragmentary inscription appears to be another extract from a civic calendar ordering the hieropoioi, public officials, to make a sacrifice to Apollo on a specific occasion; a further sacrifice may have been mentioned in the following fragmentary traces (lines 7-9).

\section{Rhodes. Camiros. Extract of a calendar / sign (polis?) - third century BCE}

This laconic order also appears to be an extract from the official calendar (note the conjunction $\delta \varepsilon ́$ in line 1). It calls for an offering to Zeus Hyetios, associated with rain. This explains why the offering is to be performed not at a specific date, but rather "whenever it is necessary", i.e. in a period of drought.

\section{Rhodes. Camiros. Extract of a calendar / sign (polis) - first century BCE (T.Cam. 156; CGRN158)}

This appear to be another extract from the civic calendar (see the preceding items and nos. 94-97 above). The hieropoioi, public officials, are to sacrifice a goat to Dionysus at a specific date. 


\section{Rhodes. Camiros. Sign (polis) - Roman period}

Even though this regulation was enacted on a proposal of the archontes and contains an enactment formula indicating that it was approved by the koinon of the people of Camiros and the mastroi, it should be classified as a sign because of its brevity. It no doubt contains an excerpt of a larger document, i.e. a law/decree. There is a regulation against burning a fire in the bierothyteion or in the stoa in front of it (lines 2-4). There is a clause in the casuistic form imposing a fine of 25 drachmas for infractions (lines 4-6). Sokolowski compares LSCG 3, line 6; 100; 112, line 3.

\section{Rhodes. Camiros. Fragment of law/decree (?) (polis?) - Hellenistic period}

This very fragmentary inscription appears to contain regulations about purification: for instance, there is to be no entry for five days after the death of a family member (lines 2-4). Very little remains of the rest, but there may be a penalty clause in the casuistic form (lines 10-12). Line 13 intriguingly mentions a citizen (polites), which would tend to point towards a public document.

\section{Rhodes. Law/decree (polis) - third century BCE}

This is a law/decree of the polis and contains enactment formulas (lines 2, 9-10). The regulations concern the placement of dedications in the sanctuary of Asclepius. Dedicators are forbidden to request that their dedications be placed in certain parts of the shrine and in places that would prevent free movement (lines 2-18). On the term aitesis used for dedications see Harris (2015), 72-74. There is a penalty clause in the casuistic form, which declares any illegal request invalid (lines 18-20). If any illegal dedications are made, the astynomoi are to remove them (lines 20-22). The inscription ends with a publication clause and an order to place the stele in the shrine of Asclepius (lines 22-28).

\section{Rhodes. Sign (polis or private association) - first century CE}

The inscription appears to contain regulations about purity for entry into a shrine (lines 4-6). One should be pure not only from washing but in mind (lines 6-7; see above, no. 82). The duration of the abstentions prescribed in the first preserved section (lines 2-3) are omitted or were specified in earlier, now missing, lines. The inscription concludes with sacrificial tariffs: those sacrificing 
should place one amount for an ox in the treasury, another for a cock (lines 812).

\section{Rhodian Peraea. Loryma. Fragment (uncertain authority) - first century CE (I.Rhod.Peraia 1)}

There appears to be a regulation about sacrifices to Zeus Atabyrios (lines 1-2). The inscription is too fragmentary for typological analysis.

\section{Rhodian Peraea. Near Tymnos. Extract of a calendar / sign (uncertain authority) - Roman period (I.Rhod.Peraia 292)}

This appears to be an extract from a calendar, but it is impossible to determine the authority, and the sign appears to have been inscribed on a block belonging to an altar (the text begins with the name of Aphrodite in the genitive, contrary to other extracts discussed above; cf. e.g. nos. 94-97). The regulation prescribes a sacrifice to Aphrodite on two different occasions.

\section{Rhodian Peraea. Tymnos. Law/decree (subdivision of the polis) - first century BCE (I.Rhod.Peraia 201)}

This is a decree of the koinon of the Tymnians (lines 1-3). The regulation adds to previous regulations (lines 3-4) and intends to accommodate those making sacrifices to Zeus and Hera for the ktoina or the demos by providing the stoa and restored/furnished buildings called chresteria for their use (lines 4-10). It is not permitted or anyone to damage the stoa and the buildings called chresteria nor to light a fire in the stoa. Nor is it permitted for anyone to nail anything to the roof or to the columns (lines 10-14). If anyone violates these rules, the bierothytas, the public slave and any members of the deme who wishes is to prevent it (lines 14-16). The person who disobeys is to be registered with the hierotamiai as owing a penalty of one hundred drachmas sacred to Apollo, and they are to destroy what has been nailed up (lines 16-18). So that the written rules be clear, that no one commits an error toward the gods, and that the statues remain unharmed and pure for as long as possible, the hierothytas in office is to inscribe this decree in the stoa on the opposite wall (lines 18-22). 


\section{Lato. Law/decree (polis?) - fourth century BCE (IC I XVI 6; CGRN 166)}

The inscription is very fragmentary but appears to contain rules about purity (e.g. line 20), but also about other subjects such as incubation (fr. IV C). The scale and general formulation of the rules strongly suggest a public document, as does the mention of a group of priests in fr. IV A, line 4. There are clauses in the casuistic form (fr. I- III, lines 12-15, 20-24, 24; IV A, lines 1-2, B 2-5).

\section{Axos. Law/decree (polis) - fifth century BCE (IC II 9; IGFGP 107; LACA9)}

The inscription, known only from copies, appears to pertain to the perquisites of priests. There appear to be two clauses in the casuistic form. The first imposes a penalty of one stater and twice the value of the meat for priests who carry off something contrary to the written rules (lines 2-7). The amount is probably double the portion of meat the priest illegally carried off (thus Koerner in IGFGP). The second imposes an equal fine on the kosmos who does not give back what is claimed (lines 9-11). The final clause orders the Council to give twelve staters for sacrifice every other year (lit. "in the third year") for the Kydanteia, which appears to be a biennial festival (lines 11-14).

\section{Gortyn. Law/decree (?) (polis?) - fourth century BCE (IC IV 146; CGRN10)}

The inscription is fragmentary and has been interpreted in different ways. Comparetti thought it was related to purification after a plague, but Guarducci connected it with purifications of ships and sacrifice to offer when leaving a port. According to this view, line 3 would thus mention "a law of the port". For further discussion, see now CGRN.

\section{Cyrene. Law/decree (polis), presented as an oracle - ca. 325- 300 BCE (R\&O 97; SEG 50, 1638; CGRN 99)}

The rules are presented as the substance of an oracle of Apollo (lines A1-3 and following) or headed by this short three-line oracle, which apparently provided the authority for the entire document: "Apollo prophesied: forever making use of purifications and abstentions and [tithes (?)], they are to settle Libya". Whatever the authenticity of this oracle, the rules which follow present an 
elaborate code of ritual practice in the sanctuary of Apollo and Artemis at Cyrene, especially with regard to purification and abstentions. Throughout the document, there is only rarely mention of any civic authority or officials, though this may justifiably be presumed. Conspicuous exceptions include the mention of a civic shrine (damosion iaron) in line B41 and a civic highway (demosia odos) in lines B53-54. Overall, the general tenor of the rules can also be seen as indicative of civic authority, such as for instance the mention of plague or other disasters afflicting the city or its territory in lines A4-5.

The law is carefully organised into paragraphs and thematic sections. Nearly of the rules are presented in a casuistic form: viz. if such a situation arises, do the following. A first paragraph ( $\left(\int_{1} 1\right)$ discusses rules for general calamities afflicting the city or its territory, a sacrifice to Apollo Apotropaios "in front of the gates" is prescribed; $\int 2$ concerns wood growing in the sanctuary of Apollo, which may be used for different purposes if its price is paid to the god; this is followed by a section concerned with the purity of men after sex ( $(3)$ and another about the pollution of the household after a woman has given birth to a child ( $\left(\int_{4}\right)$; an enigmatic section ( $(5)$ apparently concerns the visiting of shrines and tombs for the heroic dead at Cyrene, while another ( $\mathbb{S} 6$ ) discusses the purification necessary after an illicit sacrifice; this is accompanied by a fine (zamia) in the form of the sacrifice of an adult animal. Next, come five paragraphs (\$ 7-11) concerning the equally enigmatic subject of "tithes" (dekatai). Though this process of "tithing" must somehow be connected with transgressions involving purity, the rules are now substantially obscure to us; the fine (zamia) prescribed in many cases, as above, consists in the sacrifice of an adult animal. On face B are first presented rules concerning female ritual practice and the Artemision in the sanctuary. The sections deal specifically with sacrificial and purificatory rituals for new brides ( $\int 13$ and 14), pregnant women and new mothers ( $(15)$, followed by further smaller section on impurity resulting from miscarriage ( $(16)$. Next comes a special heading, "of suppliants", in line B28, followed by three paragraphs on this subject. Here too, the rules are to some degree enigmatic: $\int 17$ in particular describes rules for dealing with a "suppliant" sent to or against a household, where the reference might be to a visitant that is the result of a magical practice rather than a human suppliant; the type of suppliant envisaged in $\int 18$ remains mysterious, referring to an "accomplishment" difficult to define, though this person is also envisaged as sitting like a suppliant "in the civic sanctuary" (either the Apollonion itself or the civic hearth). Before the lacuna and perhaps other missing parts of the dossier, we finally read more intelligible fragments of a procedure for dealing with a suppliant who is a murderer $(\Omega$ 19). Here, there is also possibly the 
mention of civic structures such as a [- - polia and a triphylia, as well as the use of the civic road (damosia odos) during the procedure for dealing with the suppliant.

\section{Cyrene. Law/decree (?) (polis?) - second century BCE (CGRN190)}

This is a list of items to be sacrificed to various gods, as well as a few other related rules (interdictions e.g. lines A6-11), but it does not seem to be a calendar because there are no dates. This should probably be a public document because the prytaneion and the agora are mentioned (lines B5-7).

\section{Cyrene. Law/decree (?) (polis?) - second or first century BCE (SEG 9, 73)}

The first lines are missing so it is impossible to know if there was a prescript. The preserved parts of the inscription contain a prohibition on using cups by anyone outside the sanctuary (lines 7-11). There is a penalty in the casuistic form with the offender subject to a legal charge of bierosylia (lines 12-15). The restoration of a curse in these lines is very doubtful. There follows an inventory of the sacred cups, which is not included by Sokolowski.

\section{Cyrene. Fragment (uncertain authority) - second century CE (SEG 9, 347)}

Not enough remains of the inscription to determine who issued the orders. Sokolowski believes that these are rules about purification posted at the entry to a sanctuary and compares $L S A M 14$ and $L S S$ 108. If that is correct, this may be a sign.

\section{Egypt. Ptolemais. Sign (sanctuary or private association?) - first century BCE (CGRN144)}

This contains a set of rules about purificatory abstentions (line 2: hagneuein) for those entering the sanctuary (line 1: tous eisiontas eis to [hieron]). There are no penalties or officials mentioned, though the conclusion of the text is fragmentary. 


\section{Cumae. Sign (private association?) - fifth century BCE (SEG 4, 92; IGASMG III 15)}

This is a sign on a boundary stone that forbids (ou themis) burial "in this place" to anyone who is not an initiate of Dionysus. This was probably intended for the burial ground of a private association. Sokolowski rightly compares LSS 126, which relates to burial and pertains to a thiasos.

\section{Ephesus. Law (polis) - third century CE (I.Ephesos 10)}

This is a summary of a traditional or ancestral law (patrios nomos, line 2). It contains two principal sections: lines 3-17 and 17-33 (the latter identified as allo meros). The law gives orders to the prytanis to perform rituals and to make sacrifices on the advice of the public bierophant (esp. lines 10-12). Paeans are to be sung and prayers for the holy synod, the Roman people and the people of Ephesus (lines 12-17). The prytanis is to give perquisites to the bierophant and other sacred officials (lines 18-25). There is a penalty for the prytanis in the casuistic form for not performing his duties of ten Daric staters (lines 25-30), which the kouretai and the bierophant are to impose (lines 30-33).

\section{Miletus. Fragment (polis?) - around 497 BCE (Milet VI 3, 1217)}

The fragment (B) as given in Sokolowski is impossible to analyse typologically. Sokolowski believes it relates to perquisites for priests. The new edition in Milet VI 3 groups the fragment in Sokolowski (B) with another (A), where sacrificial rules are a bit clearer, though the classification of the document remains quite uncertain.

\section{Miletus. Sign or extract of a law/decree (polis) - third century BCE (Milet I 3, 32)}

This has an enactment formula (line 1), but is very brief and placed on the architrave of a stoa: it is probably an extract or summary of a civic law or decree about religious matters that was placed in this position in the shrine of Apollo as a sign. It forbids the placement of dedications next to the wooden ceiling or the columns of the stoa and orders that they be placed next to the walls beneath (lines 1-4). There is a penalty clause in the casuistic form (line 4), of four staters, but no official named. 


\section{Athens. Law/decree (deme) - fourth century BCE $\left(I G \mathrm{II}^{2}\right.$ 1184; CGRN79)}

This is a law/decree of Cholargos, the deme of the Cholargeis (lines 19-20), which orders the female officials for the Thesmophoria, in lieu of the priestess (of Demeter), to contribute certain types of food (barley, wheat, grain, wine, olive oil, honey, sesame, cheese, etc.) and drink for the festival. There is no preamble, but the beginning of the document is fragmentary; a partly preserved earlier section mentions the bieromnemones, probably public officials of the deme or the Athenian state. The deme decree concludes with a publication clause (lines 18-25).

\section{Athens. By-law (private association) - third century BCE (IG II $^{2}$ 1242)}

This appears to be a by-law of a private association, the orgeones of (Artemis) Hegemon (lines 9-10). It calls for the election of ten men so that rituals will be carried out as spendidly as possible (lines 1-4). Five are to be elected from Dekeleia, five from another area (not preserved; lines 4-6). There also appears to be an order to the bieropoioi to distribute meat to the orgeones and the perquisites (lines 6-10).

\section{Attica. Piraeus. By-law (private association) - late third or early second century BCE $\left(I G I^{2} 1275\right)$}

This orders relatives and friends in the thiasos to attend the ekphora of members who are deceased (lines 1-7). If any member is wronged, the members are ordered to help this person (lines 7-10). The document ends with an entrenchment clause allowing anyone to make an accusation and the association to impose any penalty it decides (lines 12-17).

\section{Athens. By-law (private association) - Roman period (IG $\mathrm{II}^{2}$ 1346)}

The regulations contains an enactment clause (line 4) followed by the definite article in the feminine dative plural, which suggests a private association or cultic group of women. The woman appointed priestess is to hand over to her successor all items from the cult (lines 5-8). The one who succeeds is to look after all the property of the group (lines 8-12). If anyone does not turn over 
what she has received, she is to owe the expense (for replacing the items?), and her successor can collect the sum from her (lines 12-16). No one is allowed to move the furniture (lines 16-18). The woman who is about to take up office is to swear in Skirophorion that she will guard the property of the gods and the property of the shrine so that the rites will be carried out piously (lines 18-27). The inscription concludes with a publication formula and an order to sanctify (kathierosai) the decision for all time (lines 27-29).

\section{Aetolia. Kallion. Sign (polis or private association?) - fifth century BCE}

This is a sign because of its brevity: it forbids entry to the shrine (lines 1-2) and imposes a fine of four staters for violations (lines 3-6). There is no enactment formula or officials named.

\section{Chios. Sign or extract/summary of a law/decree (polis?) - fifth century BCE (CGRN36)}

The document gives perquisites for a priest of Pelinaios (lines 1-7). If the priest is not present, anyone may shout three times, then sacrifice (lines 7-11). There is a prohibition against giving something (Forrest in SEG 17, 377 thinks of grains of wheat-actually this concerns providing the perquisites "to anyone else") and a penalty clause in the casuistic form for violations (lines 13-16), of an amount of five staters, though it is not clear if this applies to the priest or to worshippers (perhaps to both, in fact). No other official is named, but given the hefty fine and the publication of these rules for the mountain sanctuary in the city, it seems likely that this is a public document presented in abbreviated form.

\section{Chios. Fragment (civic subdivision-genos?) - fourth century BCE $(S E G 17,378)$}

Forrest argued that this appears to be a fragment of a regulation concerning priestly prerogatives, perhaps belonging to a genos (see line 1, with Sokolowski's notes). This is possible, but not established beyond doubt. For such a regulation clearly belonging to a genos on Chios, compare LSCG 119. 


\section{Chios. Sacrificial calendar (civic subdivision-genos?) - early fifth century BCE (Graf 1985: Chios no. 1)}

Though fragmentary, this appears to be a brief calendar of sacrifices: only two dates are mentioned and no precise offerings are recorded, before the fragment trails off. Since the inscription comes from the hinterland of the island of Chios, it may well belong to a civic subdivision of the polis. Compare the extracts from the sacrificial calendar found on the island of Rhodes (nos. 94-97 etc. above).

\section{Attica. Teithras. Sacrificial calendar (deme) - fourth century $\mathrm{BCE}$ and a more recent fragment (CGRN 55)}

Fragment A contains a list of sacrifices at two different dates in the month of Boedromion with itemised accounting of the prices for each offerings required, as well as for the priestly prerogatives (biereosyna). Fragment B preserves some traces of offerings, perhaps reflecting a newer form of the calendar.

\section{Cyrene. Sign (uncertain authority) - third century BCE (SEG 20,718)}

This appears to be a sign on a marble plaque which introduces a shrine of Hekate (line 1). The sacrificial rule prohibits the offering of incense.

Edward HARRIS

University of Durham

edward.harris@durham.ac.uk

Collège de France / University of Liège

assisted by Jan-Mathieu CARBON

jan-mathieu.carbon@college-de-france.fr / jmcarbon@uliege.be

\section{Abbreviations (numbers refer to inscriptions)}

CGRN: Carbon, J.-M., Peels, S., and Pirenne-Delforge, V. (2017-) Collection of Greek Ritual Norms, Liège [http://cgrn.ulg.ac.be/].

Choix Delphes: Jacquemin, A., Mulliez, D. and Rougemont, R. (2012) Choix d'inscriptions de Delphes, traduites et commentées, Athens.

IE: Clinton, K. (2005) Eleusis, The Inscriptions on Stone, 2 vols., Athens. 
IGASMG III: Arena, R. (1994) Iscrizioni greche arcaiche di Sicilia e Magna Grecia, Vol. 3: Iscrizioni delle colonie euboiche, Pisa.

IGFGP: Koerner, R. (1993) Inschriftliche Gesetətexte der Frühen Griechischen Polis, Cologne/Weimar/Vienna.

LAC: Gagarin, M. and Perlman, P., The Laws of Ancient Crete c.650-400 BCE, Oxford.

\section{Bibliography}

Alessandrì, S. (1980) "IG II2 40 (Una proposta di lettura)", ASNP10.4: 11311161.

Broneer, O. (1932) "Eros and Aphrodite on the North Slope of the Acropolis in Athens," Hesperia 1: 31-55.

Canevaro, M. (2013a) The Documents in the Attic Orators: Laws and Decrees in the Public Speeches of the Demosthenic Corpus, Oxford.

Canevaro, M. (2013b) "Nomothesia in Classical Athens: What Sources should we believe?," CQ 63.1: 139-160.

Canevaro, M. and Harris, E. M. (2012) “The Documents in Andocides' On the Mysteries", CQ 62: 98-129.

Canevaro, M. and Harris, E. M. (2016) "The Authenticity of the Documents at Andocides' On the Mysteries 77-79 and 83-84," Dike 19: 7-48.

Clinton, K. (1974) The Sacred Officials of the Eleusinian Mysteries, Philadelphia.

de Ligt, L and de Neeve, P. (1988) "Ancient Periodic Markets, Festivals and Fairs," Athenaeum 66: 391-416.

Delli Pizzi, A. (2011) “Impiety in Epigraphic Evidence”, Kernos 24: 59-76.

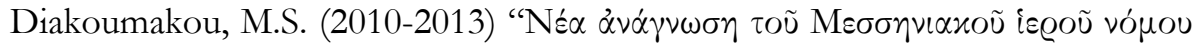
(IG V 1, 1316)", Horos 22-25: 241-249.

Dimitrova, N. (2008), Theoroi and initiates at Samothrace, Princeton.

Feyel, C. (2009) Aoxuaбía. La place et le rôle de l'examen préliminaire dans les institutions des cités grecques, Nancy.

Fournier, J. and Hamon, P. (2007) "Les orphelins de guerre de Thasos : un nouveau fragment de la stèle des braves (ca 360-350 av. J.-C.)”, BCH 131: 309-381.

Gauthier, P. (1972) Symbola. Les étrangers et la justice dans les cités grecques, Nancy.

Gauthier, P. (1980) “Études sur des inscriptions d'Amorgos", BCH 104: 197220. 
Gauthier, P. (1984) "La dokimasia des victimes. Note sur une inscription d'Entella," ASNP 14.3: 845-848.

Gonzales, M. (2008) "New Observations on the Lindian Cult: Tax for Enyalios (SEG 4.171)", ZPE 166: 121-134.

Graf, F. (1985) Nordionische Kulte: Religionsgeschichtliche und epigraphische Untersuchungen zu den Kulten von Chios, Erythrai, Klazomenai und Phokaia, Rome.

Habicht, C. (1957) "Eine Urkunde des Akarnanischen Bundes", Hermes 85: 86122.

Hamon, P. (2010) "Études d'épigraphie thasienne, III. Un troisième fragment de la Stèle des Braves et le rôle des polémarques à Thasos”, BCH 124: 301315.

Harris, E. M. (1990) “The Constitution of the Five Thousand," HSCP 93: 243280.

Harris, E.M. (2015) "Towards a Typology of Greek Regulations about Religious Matters: A Legal Approach”, Kernos 28: 53-83.

Harris, E.M. (2015b) "The Family, the Community and Murder: The Role of Pollution in Athenian Homicide Law", in Ando, C. and Rüpke, J. eds. Public and Private in Ancient Mediterranean Law and Religion, Berlin/Boston: 11-35.

Harris, E.M. (2016) "From Democracy to the Rule of Law? Constitutional Change in Athens during the Fifth and Fourth Centuries BCE", in Tiersche, C. ed. Die Athenische Demokratie im 4. Jahrbundert: Zwischen Modernisierung und Tradition, Stuttgart: 73-87.

Henrichs. A. (1983) “The 'Sobriety' of Oedipus: Sophocles OC 100 Misunderstood," HSCPh 87: 87-100.

Kah, D. (2012) "Eine Neue Brunneninschrift aus Priene”, EA 45: 55-70.

Lambert, S.D. (1997) "The Attic Genos Salaminioi and the Island of Salamis", ZPE 119: 85-106.

Lambert, S.D. (2002) “The Sacrificial Calendar of Athens”, BSA 97: 353-99.

Liddel, P. (2003) "The Places of Publication of Athenian State Decrees from the $5^{\text {th }}$ century BC to the $3^{\text {rd }}$ Century AD", ZPE 143: 79-93.

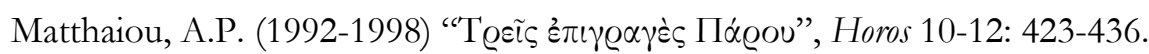

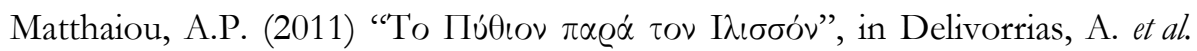
eds. "Eлaıvos Luigi Beschi, Athens: 259-271.

Migeotte, L. (1992) Les souscriptions publiques dans les cités grecques, Geneva / Quebec.

Mikalson, J. (1975) The Sacred and Civil Calendar of the Athenian Year, Princeton. 
Miles, M.M. (1998) The City Eleusinion, Princeton.

Ogden, D. (1996) Greek Bastardy in the Classical and Hellenistic Periods, Oxford. Papazarkadas, N. (2011) Sacred and Public Land in Ancient Athens, Oxford.

Petrovic, I. and Petrovic, A. (2016) Inner Purity and Pollution in Greek Religion, Vol. 1: Early Greek Religion, Oxford.

Petrovic, I. and Petrovic, A. (2018) "Purity of body and soul in the cult of Athena Lindia: On the eastern background of Greek abstentions", in Carbon, J.-M., and Peels, S. eds. Purity and Purification in the Ancient Greek World: Texts, Rituals, and Norms, Liège: 225-258.

Pitz, Z. (2016) “La complexité d'Héraclès, entre Hérodote et les cultes de Thasos", Kernos 29: 101-118.

Purvis, A. (2003) Singular Dedications: Founders and Innovators of Private Cults in Classical Greece, New York/London.

Rosivach, V.J. (1994) The System of Public Sacrifice in Fourth-Century Athens, Atlanta.

Rutherford, I. (2013), State Pilgrims and Sacred Observers: A Study of Theoria and Theoroi, Cambridge.

Stavrianopoulou, E. (2011) "'Promises of continuity': The role of tradition in the forming of rituals in ancient Greece", in Chaniotis, A. ed. Ritual Dynamics in the Ancient Mediterranean: Agency, Emotion, Gender, Representation, Stuttgart: 85-103.

Stroud, R.S. 1974. “An Athenian Law on Silver Coinage,” Hesperia 43: 157-188. 